\title{
The Cellular and Molecular Bases of Allergy, Inflammation and Tissue Fibrosis in Patients with IgG4-related Disease
}

\author{
Song-Chou Hsieh ${ }^{1,}{ }^{\dagger}$, Chieh-Yu Shen ${ }^{1}$, Hsien-Tzung Liao ${ }^{2}$, Ming-Han Chen ${ }^{2}$, Cheng-Han Wu ${ }^{1}$, \\ Ko-Jen Li ${ }^{1}{ }^{\circledR}$, Cheng-Shiun Lu ${ }^{1}{ }^{1}$, Yu-Min Kuo ${ }^{1}$, Hung-Cheng Tsai ${ }^{2}$, Chang-Youh Tsai ${ }^{2, *}+{ }^{+}$ \\ and Chia-Li Yu ${ }^{1, *}$ \\ 1 Division of Rheumatology, Immunology \& Allergy, National Taiwan University Hospital, National Taiwan \\ University College of Medicine, Taipei 10002, Taiwan; hsiehsc@ntu.edu.tw (S.-C.H.); \\ tsichhl@gmail.com (C.-Y.S.); chenghanwu@ntu.edu.tw (C.-H.W.); dtmed170@yahoo.com.tw (K.-J.L.); \\ b89401085@ntu.edu.tw (C.-S.L.); 543goole@gmail.com (Y.-M.K.) \\ 2 Division of Allergy, Immunology \& Rheumatology, Taipei Veterans General Hospital \& National Yang-Ming \\ University, Taipei 11217, Taiwan; darryliao@yahoo.com.tw (H.-T.L.); meikankimo@yahoo.com.tw (M.-H.C.); \\ hctsai7@vghtpe.gov.tw (H.-C.T.) \\ * Correspondence: cytsai@vghtpe.gov.tw (C.-Y.T.); chialiyu@ntu.edu.tw (C.-L.Y.); \\ Tel.: +886-2-28712121 (ext. 3366) (C.-Y.T.); +886-2-23123456 (ext. 65011) (C.-L.Y.) \\ + These authors contributed equally to this work.
}

Received: 16 June 2020; Accepted: 14 July 2020; Published: 18 July 2020

\begin{abstract}
IgG4-related disease (IgG4-RD) is a spectrum of complex fibroinflammatory disorder with protean manifestations mimicking malignant neoplasms, infectious or non-infectious inflammatory process. The histopathologic features of IgG4-RD include lymphoplasmacytic infiltration, storiform fibrosis and obliterative phlebitis together with increased in situ infiltration of IgG4 bearing-plasma cells which account for more than $40 \%$ of all IgG-producing B cells. IgG4-RD can also be diagnosed based on an elevated serum IgG4 level of more than $110 \mathrm{mg} / \mathrm{dL}$ (normal $<86.5 \mathrm{mg} / \mathrm{mL}$ in adult) in conjunction with protean clinical manifestations in various organs such as pancreato-hepatobiliary inflammation with/without salivary/lacrimal gland enlargement. In the present review, we briefly discuss the role of genetic predisposition, environmental factors and candidate autoantibodies in the pathogenesis of IgG4-RD. Then, we discuss in detail the immunological paradox of IgG4 antibody, the mechanism of modified Th2 response for IgG4 rather than IgE antibody production and the controversial issues in the allergic reactions of IgG4-RD. Finally, we extensively review the implications of different immune-related cells, cytokines/chemokines/growth factors and Toll-like as well as NOD-like receptors in the pathogenesis of tissue fibro-inflammatory reactions. Our proposals for the future investigations and prospective therapeutic strategies for IgG4-RD are shown in the last part.
\end{abstract}

Keywords: IgG4-related disease; fibroinflammatory disorder; lymphoplasmacytic infiltration; storiform fibrosis; obliterative phlebitis; modified Th2 response; follicular helper T cell; $\mathrm{CD} 4{ }^{+}$cytotoxic T cell; Fab-arm exchange

\section{Introduction}

IgG4-related disease (IgG4-RD) is a newly defined multiorgan immune-mediated fibroinflammatory disorder with protean clinical manifestations [1-8]. In general, human immunoglobulins (IgGs) contain four subtypes, IgG1 through IgG4, of which IgG4 is the scarcest. Nevertheless, IgG4-RD is characterized by elevated serum IgG4 levels together with tissue infiltration by IgG4-secreting lymphoplasmacytic 
cells. The IgG4-secreting plasma cell infiltration may cause swelling, inflammation and finally fibrosis of organs mimicking malignant tumors [6-9]. The commonly involved organs include pancreas, liver, bile duct, major salivary glands, lacrimal glands, lungs, kidneys, aorta, thyroid glands, lymph nodes, retroperitoneum, prostate, pachymeninx and other tissues/organs, thus leading to a broad spectrum of protean clinical features as shown in Table 1.

It was accepted that histopathologic findings are crucial for the diagnosis of IgG4-RD. The essential pathologic characteristics including lymphoplasmacytic infiltration, storiform fibrosis and obliterative phlebitis should be confirmed in the biopsy specimens [10-12]. These tissue-infiltrating B lymphocytes and plasma cells are polyclonal in nature. In addition, eosinophils are commonly present in the lesions. However, no or rare neutrophilic infiltration or necrosis can be found in the tissues. Another distinctive histopathologic finding in IgG4-RD is the storiform fibrosis. This particular fibrosis appears as an irregular whorled or cartwheel-like organization of the collagen bundles in the tissue, which is presumably produced by the myofibroblasts (MFBs) after activation by profibrotic stimuli during inflammation. However, it is also accompanied scarcely by spindle cells infiltration in the affected tissues [12]. Obliterative phlebitis is characteristic of luminal obliteration by inflammatory cells and fibrosis next to a patent artery. Table 1 summarizes the wide spectrum of protean clinical manifestations and the nature of the characteristic histopathologic findings in patients with IgG4-RD. Although clinical, serologic, radiological and pathologic features are all contributory to the classification of IgG4-RD, none of them alone can fulfill the classification criteria. Therefore, the 2019 ACR-EULAR classification criteria for IgG4-RD agreed to contain both exclusion and inclusion standards [13].

Table 1. A wide range of protean clinical manifestations and characteristic histopathologic findings in patients with IgG4-related disease.

\begin{tabular}{ll}
\hline & (1) Clinical manifestations [1-8] \\
\hline Type 1 autoimmune pancreatitis & IgG4-related pachymeningitis \\
IgG4-related dacryoadenitis & IgG4-related hypophysitis \\
IgG4-related sialoadenitis & IgG4-related aortitis/periaortitis/arteritis \\
& /mediastinitis/mesenteritis \\
Küttner's tumor (submandibular sialodenitis) & IgG4-related pleuritis/pericarditis \\
Mikulicz's disease (sialoadenitis +dacryoadenitis) & InG4-related mastitis \\
IgG4-related orbital myositis & Ormond's disease (retroperitoneal fibrosis) \\
Riedel's thyroiditis & IgG4-related membranous glomerulonephritis \\
IgG4-related allergic rhinitis & IgG4-related ureteritis/urethritis \\
IgG4-related asthma & IgG4-related prostatitis \\
IgG4-related chronic rhinosinusitis & IgG4-related skin diseases \\
IgG4-related lung disease / pseudotumor & IgG4-related lymphadenopathy \\
& IgG4-related midline destruction lesion \\
IgG4-related sclerosing cholangitis & \\
IgG4-related cholecystitis & \\
IgG4-related hepatitis & \\
\hline
\end{tabular}

(2) Characteristic histopathological features [9-12]

Lymphoplasmacytic infiltration: IgG4 (+) plasma cell/IgG (+) plasma cell ratio $>40 \%$

Storiform fibrosis: irregular whorled organization of the collagen bundles throughout the tissue led by the activation of myofibroblasts after profibrotic stimuli of inflammation

Eosinophil, but not neutrophil infiltration, is commonly present

Absence of granuloma or tissue necrosis

Obliterative phlebitis: partial or complete obliteration of medium-sized veins by lymphoplasmacytic cell infiltration appearing as an inflammatory nodule next to a patent artery

\section{Genetic Predisposition in Patients with IgG4-RD}

IgG4-RD is regarded as a complex autoimmune-mediated fibroinflammatory disorder in which type 1 autoimmune pancreatitis (AIP) is the archetype. Although a number of genetic loci have been found associated with AIP, these genetic predispositions are not consistent with the actual features 
described more recently because no one of them can well define the disease entity. Here, we only cite the genetic studies after genome-wide association study (GWAS) has been published. In this regard, Oguchi et al. [14] by reference from GWAS, have found that KLF7, FRMD4B, LOC101928923 and MPPED2 are the susceptibility genes that trigger lacrimal and salivary gland lesions in Japanese patients with type 1 AIP.

The mammalian homologs of yeast sterile 20 (STE 20)-like kinases (MST), MST1 MST4 and YSK1, belong to serine/threonine kinases, playing crucial roles in the control of immune cell trafficking, proliferation, differentiation and apoptosis [15]. Siedel et al. [16] have found that MST1 locus contains CpG islands in its promoter region and suggested that the epigenetic regulation of MST1 could control immune responses. Fukuhara et al. [17] have demonstrated that decreased expression of MST1 due to hypermethylation in the promoter region in regulatory T cells (Treg) can lead to IgG4-related AIP.

Fibroblast growth factor-binding protein 2 (FGFBP2) secreted by cytotoxic T lymphocytes can potently bind to FGF to enhance collagen fiber synthesis by fibroblasts (FBs). The variant sequence in FGFBP2 after binding to FGF is predicted to form a distorted coil morphology of collagen fibers as found in the storiform fibrotic tissue in IgG4-RD rather than a normal helical-turn-helix fibril structure [18]. Newman et al. [19] have reported that FGFBP2 variant is highly prevalent in circulating $\mathrm{CD}^{+}$cytotoxic $\mathrm{T}$ cells $\left(\mathrm{CD} 4^{+} \mathrm{Tc}\right)$ in a family rather than in sporadic IgG4-RD patients.

\section{Intestinal Dysbiosis in Animal Model and Patients with IgG4-RD}

\subsection{Induction of AIP by Persistent Exposure to Intestinal Commensal Flora Antigens in Animal Models}

Haruta et al. [20] have explored the potential effect of chronic exposure (1 week $\sim 12$ months) of a mouse model to killed E. coli in the pathogenesis of IgG4-RD. They have concluded that a persistent stimulation of pathogen-associated molecular pattern (PAMP) activator to innate immune system may ultimately lead to the occurrence of AIP associated with salivary gland lesions which is probably through molecular mimicry. Yanagisawa et al. [21] have further identified the outer membrane protein flagellin (FliC) of the commensal flora could induce AIP-like pancreatitis with generation of high titer of anti-lactoferrin and anti-CA II antibodies in mice after repeated inoculation. These results emphasize the importance of commensal bacteria in inducing AIP via PAMP recognizing receptors. Following this way, many authors have also demonstrated that intestinal commensal microflora-released danger-associated molecular pattern (DAMP) activator can bind to Toll-like receptors (TLRs) or nucleotide-binding oligomerization domain-like receptor (NOD-like receptors, NLRs) on basophils to skew naïve T lymphocytes to Th2 responses for the development of IgG4-RD [22-26].

\subsection{Intestinal Dysbiosis-mediated AIP}

It is believed that gut microbiome participates in the development of host immune system. Ahuja et al. [27] have demonstrated that antimicrobial peptides secreted by pancreatic acinar cells can shape the gut microbiome crucial for intestinal innate immunity, barrier function and host survival. Mice lacking acinar $\mathrm{Ca}^{2+}$ channel, Orai 1, exhibit intestinal bacterial outgrowth and dysbiosis, which ultimately lead to inflammation and death. Hamada et al. [28] have conducted a comprehensive analysis of gut microbiota in patients with type 1 AIP by next generation DNA sequencing (NGS). They have found that gut microbiota profile in AIP was different from that in chronic pancreatitis (CP) in that the proportions of Bacteroides, Streptococcus and Clostridium species were lower in patients with AIP. Recently, Kamata et al. [29] have confirmed that activation of innate immune response by repeated administration of intestinal microflora-derived polyinosinic-polycytidylic acid could stimulate plasmacytoid dendritic cell $(p \mathrm{DC})$ to produce IFN- $\alpha$ and IL-33 with eventual development of experimental AIP. Putting these data together, intestinal dysbiosis can activate $p$ DC to induce type 1 experimental AIP.

Table 2 summarizes the possible genetic factors and intestinal microflora in the pathogenesis of IgG4-related AIP. 
Table 2. Genetic loci and intestinal microflora involved in the pathogenesis of IgG4-related autoimmune pancreatitis (AIP).

\section{(1) Genetic loci}

KLF7, FRMD4B, LOC101928923, MPPED2 in Japanese AIP associated with lacrimal/salivary gland lesions [14] Decreased $M S T_{1}$ of regulatory $\mathrm{T}$ in Japanese AIP with extra-pancreatic lesions [17] FGFBP2 (fibroblast growth factor binding protein type 2): single base deletion in IgG4-RD [19]

\section{(2) Persistent exposure of intestinal commensal flora antigen in mouse AIP model}

Avirulent E. coli (as PAMP activator) induces anti-CA II, anti-LF and ANA in mouse AIP with salivary gland involvement [20]

Commensal E. coli-derived membrane protein flagellin (FliC) induces AIP-like inflammation in mouse model [21]

Intestinal microflora can activate TLRs and NLRs on basophils to promote Th2 skewing and IgG4 production in the presence of BAFF [22-26]

\section{(3) Intestinal dysbiosis-mediated AIP development via $p$ DC activation}

Decrease in gut Bacteroides, Streptococcus and Clostridium species in patients with AIP, compared to chronic pancreatitis [28]

Activation of $p$ DC by innate immune responses against intestinal dysbiosis in experimental mouse AIP [29]

BAFF-B cell-activating factor of TNF family; $p$ DC-plasmacytoid dendritic cell; CA—carbonic anhydrase; LF-lactoferrin; ANA—antinuclear antibodies.

\section{Autoantibody Diversity in Patients with IgG4-RD}

Carbonic anhydrases (CAs) are extremely basic zinc metallo-enzymes with a wide phyletic distribution. The enzyme family is important for acid-base regulation and at least seven isoenzymes (CA I-CA VII) were found in mammals [30]. Inagaki et al. [31] have reported that individuals suffering from autoimmune diseases including systemic lupus erythematosus (SLE) and Sjögren's syndrome produced a novel antibody against a $60-\mathrm{kDa}$ molecule that is identified as CAs. Nishimori et al. [32] have immunized PL/j mice intradermally with human CA II in adjuvant to induce autoimmune sialoadenitis. Besides CAs, lactoferrin (LF), a red iron-binding protein, is also present mainly in the secretion of body fluid such as pancreatic juice. Many authors successively demonstrated that anti-LF and anti-CA II [33-35], anti-CA I and anti-CA II [33], and anti-CA IV [36] were common nonspecific autoantibodies found in patients with AIP. Whether these autoantibodies are relevant to pathogenesis of AIP needs further investigations. Recently, a number of autoantibodies have been successively discovered by authors in addition to antibodies against CAs and LF. These unique autoantibodies include anti-pancreatic secretory trypsin inhibitor-1 (PST1) [37], anti-plasminogenbinding protein (PBP) of $H$. pylori [38], anti-pancreatic trypsinogens, $\mathrm{PRSS}_{1}$ and $\mathrm{PRSS}_{2}$ [39], anti-13.1 $\mathrm{kDa}$ protein in systemic IgG4-related plasmacytic syndrome (SIPS) [40] and anti-amylase- $\alpha 2 \mathrm{~A}$ [41]. Anti-prohibitin [42,43], anti-galectin-3 [43-45], anti-annexin $\mathrm{A}_{11}$ [43,46], anti-laminin 511- $\mathrm{E}_{8}$ [43,47] and anti-monomeric C-reactive protein (anti-mCRP) have been found in acute interstitial nephritis [48]. Table 3 summarizes the autoantibodies found in the patients with IgG4-RD. However, most of these autoantibodies belong to IgG1 subclass and only a minor proportion of them are IgG4 subtype. Since IgG4 is unable to activate complements and bind to Fc $\gamma R$, it remains to be answered whether autoantibodies of IgG4 subclass are pathogenic or only represent an over-reactivity to undetermined antigen, which will be discussed in detail in Section 5.2.

Aoki et al. [49] have incubated serum obtained from AIP patients with normal pancreas, liver, bile duct and salivary gland. They have found these serum samples containing IgG4 subclass antibodies that could bind to the epithelial cells from these organs. Furthermore, Shiokawa et al. [50] have injected circulating IgGs from IgG4-RD subjects into neonatal male BALB/c mice to examine their pathogenic activity. They concluded that both IgG1 and IgG4 from IgG4-RD exhibited pathogenic activity via binding to the affected tissue in this mouse model. 
Table 3. The presence of autoantibodies in patients with IgG4-related disease.

Anti-carbonic anhydrase II [33-35]
Anti-carbonic anhydrase I [33] and IV [36]
Anti-pancreatic secretary trypsin inhibitor-1 (PST1) [37]
Anti-plasminogen-binding protein (PBP) of H. pylori [38]
Anti-pancreatic trypsinogens PRSS1 and PRSS2 [39]
Anti-amylase-2A [41]
Anti-prohibitin [42,43]
Anti-galectin-3 [43,45]
Anti-annexin A11 [43,46]
Anti-laminin 511-E8 [43,47]
Anti-monomeric C-reactive protein (mCRP) in acute interstitial nephritis [48]

\section{Development of IgG4 Antibodies by Modified Th2 Response}

The production of immunoglobulins (Igs) is carried out by B cells in the presence of helper T cells. The IgG class is more complex in structure and biology than we think. The synthesis of IgG1, IgG2b, IgG3, IgG4 and IgE requires the help from Th2 cells whereas IgG2a synthesis is dependent on Th1 help. The most abundant IgG1 level in serum ranges from $5-10 \mathrm{mg} / \mathrm{mL}$ whereas the least abundant subclass IgG4 ranges from $0.35-0.51 \mathrm{mg} / \mathrm{mL}$. However, in case of IgG4-RD, the serum levels of IgG4 may elevate to higher than $130 \mathrm{mg} / \mathrm{mL}$. Aalberse et al. [51] have demonstrated that IgG4 antibodies commonly arise after long-term exposure to an antigen by a modified Th2 response such as in a scenario of allergen desensitization therapy. Thereby, the production of IgG4 antibody can reduce the degree of chronic allergic or inflammatory reaction to environmental stimuli by displacing the binding of IgG1 or IgE antibodies with their cognate antigens or allergens. Another two important unique properties of IgG4 antibodies are low binding affinity to $\mathrm{C} 1 \mathrm{q}$ and $\mathrm{Fc} \gamma \mathrm{R}$ on immune cells. These two unique immunological properties may originate from "Fab-arm exchange" between two IgG4 molecules to become asymmetrical antibodies with two different antigen-binding sites called as "bi-specific monovalent antibody for a given antigen" (Please see the next section in detail.)

\subsection{Modified Th2 Response for the Class-switch from IgE to IgG4}

It is well established that there are strong links between IgG4 and IgE. Usually, IgG4 responses are connected with IgE-mediated allergic reaction since both antibodies are induced by Th2 cytokines, mainly IL-4 and IL-13 [52]. However, the two cytokine receptors are distinct since production of IgE antibodies often occurs before IgG4 [53]. Thus, a 'modified Th2 response' is defined as "presence of IgG4 antibodies in the absence of IgE antibodies" [54]. Aalbese et al. [55] have further reported that DNA encoding IgG4 is upstream to the DNA encoding IgE and is deleted during the class switch to IgE in normal situation. However, Jeanine et al. [56] have demonstrated that the key cytokine driving "reverse" IgE/IgG4 class switch in the modified Th2 response is IL-10 which promotes IgG4 production but inhibit IgE production.

Recent investigations by van der Neut Kolfschoten et al. [57] have demonstrated that in the context of an allergic response, IgE-producing plasma cells require not only IL-4, but IL-5, IL-6, IL-7, IL-9 and IL-13 to help synthesize IgE. In addition to Th2 cytokines, $\mathrm{T}$ follicular helper 2 ( $\mathrm{T}_{\mathrm{fh}}$ ) cell-derived cytokine, IL-21, is also involved in determining IgG4/IgE ratio [58,59]. Recently, Akiyama et al. [60] have confirmed that IgG4/IgG ratio was statistically higher in the presence of IL-4 alone than in the presence of $\mathrm{T}_{\mathrm{fh} 2}$ cytokines including IL-21 alone in patients with IgG4-RD, but not in healthy individuals. In brief conclusion, IL-10 is implicated in the class switch from IgE to IgG4 production. Furthermore, IL-10 is needed for driving the differentiation of IgG4-class-switched B cells to IgG4-secreting plasma cells. IL-21 also exerts a similar effect with IL-10 and is one of the major cytokines that drive IgG4 shift. 


\subsection{Odd Immunological Properties of IgG4 Antibody}

5.2.1. Fab-arm Exchange Between 2 Different IgG4 Antibodies Resulting in Non-inflammatory Properties of IgG4 Antibody

Van der Zee et al. [61,62] are the 1st researcher to note that human IgG4 antibodies against allergen is unable to link across the identical antigens, in which functional change to monovalency of IgG4 antibodies is suspected. This unique immunological property can be applied in the allergen-induced immunotherapy (AIT) and the production of IgG4-therapeutic antibodies in clinical practice [63-66]. Aalberse et al. [67] have compared the $\mathrm{CH} 3$ domain of IgG1 and IgG4 and found 3 amino acid differences at glutamine (Q)355 in IgG4 vs. arginine (R)355 in IgG1, (R)409 in IgG4 vs. lysine (K)409 in IgG1 and L445 in IgG4 vs. P445 in IgG1. Because residue 409 is located in the interface between the two CH3 domains, the mutation $(\mathrm{K} \rightarrow \mathrm{R})$ may affect the stability of the non-covalent interaction between H-chains. In contrast, Schuurman et al. [68] observed that cross-linking of two non-identical antigens by IgG4 antibodies may occur via bi-specificity of IgG4 antibodies. In exploring the molecular basis of IgG4 Fab-arm exchange in the core sequence of IgG4 hinge region (residues 226-230), Aalberse group [69,70] have found a replacement of serine $(\mathrm{S})$ for proline $(\mathrm{P})$ in this interval promotes formation of intrarather than inter- $\mathrm{H}$ chain disulfide bonds. However, the dissociation of the $\mathrm{CH} 3$ domains seems to be a rate-limiting step in the Fab-arm exchange process [51,70-73]. The "Fab-arm exchange" property of IgG4 antibody leads to the formation of monovalent bi-specific antibody, a poor interaction with Fc $\gamma$ RII and/or Fc $\gamma$ RIII, an absence of complement C1q binding activity, the formation of small non-precipitating immune complexes and an eligibility for the production of therapeutic antibodies [66,67]. We have summarized the differences in the regulation, mode of action and clinical application between IgE \& IgG4 antibodies in Table 4.

Table 4. Differences in the regulation, modes of action and clinical applications between IgE and IgG4 antibodies.

\begin{tabular}{|c|c|c|}
\hline Parameters & IgE & IgG4 \\
\hline Class-switch by & IL-4, IL-13 [52] & IL-4, IL-13 [52], IL-10 \\
\hline Enhanced secretion by & $\begin{array}{c}\text { IL-5, IL-6, IL-7, IL-9 \& IL-13 } \\
{[52,55,57]}\end{array}$ & IL-10 [56], IL-21 [58-60] \\
\hline Surface receptor binding & Fc $\gamma R$ on mast cells and basophils & $\begin{array}{l}\text { Low binding to } \mathrm{Fc} \gamma \mathrm{R} \text { on immune cells } \\
\qquad[51,66,67]\end{array}$ \\
\hline $\begin{array}{l}\text { Precipitating immune } \\
\text { complexes formation }\end{array}$ & $(+)$ & $(-)[61,62,66,67]$ \\
\hline Complement activation & $(+)$ & $(-)[62,66,67]$ \\
\hline $\begin{array}{l}\text { Unique immunological } \\
\text { effects }\end{array}$ & Allergic reaction & Anti-allergen antibody $[51,53,54,64]$ \\
\hline Therapeutic application & Anti-cancer IgE antibody [54] & $\begin{array}{l}\text { Non-inflammatory monoclonal } \\
\text { antibody }[57,62-65,73]\end{array}$ \\
\hline
\end{tabular}

\subsubsection{A Unique Conformation of FG Loop in the $\mathrm{CH} 2$ Domain of IgG4 Molecule}

Davies et al. [69,71], by using high-resolution crystal structure analysis at $1.9 \AA$ and $2.35 \AA$, have revealed a unique conformation for the FG loop structure in the $\mathrm{CH} 2$ domain of IgG4 different from that of the IgG1 molecule. This loop could explain the poor Fc $\gamma$ RII, Fc $\gamma$ RIII and C1q binding capacities of IgG4 compared to IgG1 and IgG3 via preclusion of any interaction of immune complexes with the lower hinge region of IgG4 backbone and subsequent facilitation of Fab-arm exchange between two IgG4 antibody molecules [66,67]. Moreover, this $\mathrm{CH} 2$ domain in the FG loop also alters conformingly the C1q binding site [74]. 
5.2.3. Rheumatoid Factor-like Fc Binding Activity of IgG4 in the Autoimmune and Inflammatory Pathology

Contradictory to anti-inflammatory and anti-allergic activity, the IgG4 molecule per se can undergo Fc-mediated aggregation via the binding site in IgG4-CH2 and neighboring IgG4-CH3 interface to form aggregated IgG4 similar to IgG-rheumatoid factors [75]. Different from the conventional RF, which binds via its variable $\mathrm{F}_{\left(\mathrm{ab}^{\prime}\right) 2}$ domains, the activity of IgG4-" $\mathrm{RF}$ " relies on its constant $\mathrm{Fc}$ domain [51,75].

\subsubsection{Pathologic Roles of IgG4-autoantibodies in Certain Autoimmune Diseases}

It is well-known that most of the antibody-mediated autoimmune diseases are caused by IgG1 and IgG3 autoantibodies. However, Rock et al. [76] have noted that pemphigus vulgaris, a skin blister disease, is hallmarked by IgG4-autoantibodies in the affected skin tissue. To date, at least 13 IgG4-related autoimmune diseases have been reported including myasthenia gravis with muscle-specific kinase IgG4 antibody and idiopathic membranous nephropathy with IgG4 anti-phospholipase A2 receptor [77-79]. These aberrations are compatible with the observations by Aoki et al. [49] that IgG4 obtained from patients with IgG4-RD bound to normal epithelial cells and exerted pathologic effects on different tissues, which are quite different from the protective effect of IgG4 antibody to damp harmful effects of immune complexes in classical autoimmune-mediated tissue damage $[51,63,66,67]$.

5.2.5. The Glycosylation Patterns of IgG4 Molecule Induce Complement Activation in Some IgG4-RD Patients with Hypocomplementemia and Primary Sclerosing Cholangitis

Usually, the IgG4 molecule exhibits low C1q binding capacity and does not activate classical complement system as stated in Section 5.2.1. However, $40-50 \%$ of patients with IgG4-related renal inflammatory diseases are found to have soluble immune complex formation and hypocomplementemia with low C2, C4 levels and CH50 activity in the serum [80]. Nuraki et al. [81] have reported that $36 \%$ of AIP patients are with low C3 and C4 levels and 17\% of them have low $\mathrm{CH} 50$. Moreover, Deshpande et al. [82] and Cornell et al. [83] have observed that immune complex (IC) formation is playing a role in the pathophysiology of IgG4-related AIP patients. Sugimoto et al. [84] have analyzed the PEG-precipitated IC from IgG4-RD patients and found that IgG4 could participate in the activation of complements in IgG4-RD patients with hypocomplementemia. To elucidate the inconsistency in complement-activating effect of IgG4 antibody, Konno et al. [85] have analyzed the N-linked glycan of IgG4 molecule derived from patients with IgG4-RD. They found decreased galactosylation of IgGs is irrelevant to complement activation whereas IgG4 fucosylation may lead to complement activation, hypocomplementemia and various organ damages in patients with IgG4-RD. Furthermore, Culver et al. [86] have shown that an increase in IgG4-specific Fc fucosylation and hybrid structures in IgG2/3 Fc portions that are proinflammatory in nature are found in IgG4-RD and primary sclerosing cholangitis.

Putting these results together, IgG4 antibodies with particular N-glycan alterations can activate complements and are associated with hypocomplementemia in some IgG4-RD patients. We have summarized the odd immunological properties of IgG4 antibodies in patients with IgG4-RD in Table 5. 
Table 5. Odd immunological properties of IgG4 antibodies in patients with IgG4-RD.

IgG4 antibodies undergo a process of "Fab-arm exchange" to become half-antibodies with monovalency incapable of $\mathrm{C} 1 \mathrm{q}$ activation and with low binding affinity to Fc $\gamma$ RII and Fc $\gamma$ RIII resulting in non-inflammatory property [51,62,67-73]

Anti-allergic effect by attenuation of Th2 cytokine-mediated inflammation and immunosuppression $[51,53,54,63,72]$

Exhibition of rheumatoid factor-like activity by Fc-Fc aggregation to resume activating complements [51,75] IgG4 obtained from IgG4-RD subjects binds to normal epithelial cells of pancreato-hepatobiliary tissues and salivary glands in vitro [49]

Pathologic effects in certain autoimmune diseases including pemphigus foliaceus, muscle-specific kinase myasthenia gravis (MuSK MG) and idiopathic membranous nephropathy [76-80]

Complement activation and hypocomplementemia in IgG4-RD with unique-pattern glycosylation [81-86]

\section{Eosinophilia, Hyper-IgE Levels and Allergy in Patients with IgG4-RD}

It is well known that IgG4 levels rise after IgE concentration declines in the hyposensitization therapy in allergic disorders. Scientists have thus hypothesized that IgG4 perhaps emerges to shutdown allergen offense in an attempt to attenuate allergic inflammation elicited by noxious environmental allergens. It has also long been recognized that a proportion of patients with type 1 AIP have histories of allergies, peripheral eosinophilia and elevated serum IgE or manifestations of atopy during the development of AIP [87]. Van Toorenenbergen et al. [88] have demonstrated a significant correlation between total IgE and total IgG4 levels in patients with AIP and patients with atopic diseases, but not with patients with pancreatic cancer. The group has also found that the serum IgE/IgG4 ratio in patients with atopic diseases is significantly different from the ratio in patients with AIP. For exploring the roles of IgE and allergic diseases in the diagnosis as well as pathogenesis of AIP, Zhang et al. [89] have surveyed the patients with AIP. They discovered that half of their Chinese AIP patients suffered from allergic conditions whether they have high or low serum IgE levels. Those with higher IgE levels and allergic conditions suffered from more seasonal changes in pancreatic inflammation with increased mast cell number. They concluded that allergic processes may play an important role in the AIP pathogenesis. Della-Torre et al. [90] have also concluded that the processes inherent to IgG4-RD itself rather than atopy per se may contribute to eosinophilia and hyper-IgE without atopy. To solve the enigma regarding allergic reactions, eosinophilia and hyper-IgE levels in IgG4-RD, some authors have revealed that IL-10 can suppress allergen-specific accessory function of monocytes and Th2 responses, thereby decrease the IL-4-induced IgE synthesis [91-93]. As shown in Table 5, IL-10 is essential for cross-switch of IgE to IgG4 and is also crucial for IgG4 secretion by B cells. Accordingly, atopic reaction during the processes of AIP development may stimulate eosinophilia \&/or IgE production, but irrelevant to allergic reaction in $40-50 \%$ of AIP patients. Demographic study conducted by Saeki et al. [94] has shown that younger age onset, female preponderance and upper-body organ involvement are characteristic in $43 \%$ of IgG4-RD patients with allergic condition. In clinical practice, Culver et al. [95] have reported high serum IgG4 levels in $81 \%$, and high serum IgE levels in $54 \%$ of patients with IgG4-RD. Moreover, an IgE-mediated allergic response tends to develop in most of the IgG4-RD subjects. Thus, the serum IgE level could be used in the diagnosis and prediction of atopy relapse in these patients. On the other hand, whether the AIT by repeating injections of low-dose allergens to induce IgG4 class-switching from IgE to IgG4 can result in IgG4-RD remains in debate. Della-Torre et al. [96] analyzed 116 patients with biopsy-proven IgG4-RD to link AIT and IgG4-RD. Their results did not support obvious association between the two events although an increased tendency of high IgG4 in AIT group was observed. We speculate that elevated serum IgE levels is responsible for allergen-specific allergic reactions whereas serum IgG4 elevation is not the necessary parameter for the occurrence of IgG4-RD unless changes of glycosylation pattern in IgG4 molecules have occurred as stated in Section 5.2.3. 


\section{The Pathogenic Role of B Cells in Chronic Inflammation and Storiform Fibrosis in Patients with IgG4-RD}

\subsection{The Pathogenic Roles of $C D 19^{+}$Plasmablasts in AIP Patients}

Until now, the actual pathogenesis of IgG4-RD has remained elusive. The characteristic fibroinflammatory tissue in IgG4-RD contains many IgG4-producing plasmacytes/plasmablasts embedded in a fibrotic matrix that are originating from activated mesenchymal cells. New insights into cross-talk among different immune-related cells including innate immune cells, T cell subsets, B cell subset and fibroblasts/myofibroblasts have been discussed by Touzani et al. [97]. Recent studies have documented heterogeneity of the functions of B cell lineages, including cytokine secretion, antigen presentation, autoantibody production and modulation of T-B interactions, which would contribute to tolerance, autoimmunity as well as autoimmune diseases. In the tissue specimens of IgG4-RD, ectopic germinal center formation with dense infiltration by lymphoplasmacytes is prominent in salivary glands, which is probably caused by IL-21 [98]. Besides, the de novo oligoclonal expansion of circulating CD19+ plasmablasts in active and relapsing IgG4-RD has been observed, which could be used as a diagnostic biomarker for IgG4-RD independent of serum IgG4 [99]. The $\mathrm{CD}_{19}{ }^{+}$plasmablasts may produce proinflammatory cytokine (IL-1), profibrotic factors (TGF- $\beta$ and platelet derived growth factor B [PDGFB]) and a diverse autoantibodies (as shown in Table 3) in mediating tissue inflammation, destruction and fibrosis. Accordingly, anti-CD20 monoclonal antibody (rituximab) appears to be an effective treatment for IgG4-RD, even without combination of glucocorticoids in clinical practice [100]. On the other hand, regulatory B cell (Breg) mainly originating from the marginal zone of lymph nodes can produce IL-10 and TGF- $\beta$ for regulatory T cell (Treg) differentiation and Th1/Th2 polarization [101]. Sumimoto et al. [102] and Lin et al. [103] have specifically demonstrated that in addition to plasmacytes, there are two distinct Breg subsets, $\mathrm{CD} 19^{+} \mathrm{CD} 24^{\text {high }} \mathrm{CD} 27^{+}$Breg, which activates.and $\mathrm{CD} 19^{+} \mathrm{CD} 24^{\text {high }} \mathrm{CD} 38^{\text {high }}$ Breg, which suppresses the activity of AIP (please see more details in Section 8.3). Another B cell subpopulation, CD27+ memory B cell can express higher affinity cell receptor as potent APC to produce high affinity antibodies particularly in the later phases of chronic immune reaction [104]. The glucocorticoid treatment for IgG4-RD can reduce naïve B cell, circulatory plasmablasts/plasma cells and increase memory B cells [105].

Another histopathologic hallmark of IgG4-RD is the presence of storiform fibrosis in some of the affected tissues characterized by a dense tissue fibrosis with an irregular whorled organization of the collagen bundles. However, renal fibrosis is relatively rare, and interstitial nephritis as well as membranous glomerulonephritis are more frequent in IgG4-related nephropathy. On the other hand, nodal fibrosis is relatively rare, but granuloma formation is frequent in IgG4-related lymphadenopathy. It is conceivable that the histopathologic features would inevitably cause lack or scarcity of fibrosis in these two IgG4-related illness. Fukui et al. [106] have observed through transmission electron microscopy an abnormal periodicity of collagen bundles and epithelial-mesenchymal transition (EMT) of FBs to MFBs without reducing E-cadherin expression. These may lead to increases in filamentous actin and $\alpha$-smooth muscle actin, SNAIL, as well as heat shock protein 47 found in storiform fibrosis of patients with IgG4-RD.

\subsection{The Ontogenesis of MFBs}

It is believed that chronic inflammation can accelerate the progression of fibrosis in IgG4-RD. MFBs are the major effector cells of tissue fibrosis arising from FBs, pericytes, epithelium, endothelium or smooth muscle cells. After activation by fibrosis-related inflammatory mediators, the mesenchymal cells begin to trans-differentiate to MFB, proliferate and produce an excessive amount of extracellular matrix including fibrillary collagens (collagen I, III), glycoproteins (fibronectin, fibrillin, elastin and proteoglycans) and non-fibrillary collagen (collagen IV) that can deposit in the tissue [107]. 


\subsection{The Fibrosis-related Inflammatory Mediators}

Recently, a bunch of fibrosis-related inflammatory mediators have been successively discovered. These fibro-inflammatory mediators include IL-1 family (IL- $1 \alpha$, IL-1 $\beta$, IL-18, IL-33, IL-36 $\alpha$, IL-36 $\beta$ and IL-36 $\gamma$ ) [107], Th1 cytokine (IFN- $\gamma$ ) [108], Th2 cytokines (IL-4, IL-5, IL-10 and IL-13), Th17 cytokines (IL-17 and IL-22), innate immune cell-derived proinflammatory cytokines (IL-6 and TNF$\alpha$ ), growth factors (TGF- $\beta$, PDGF, CTGF, IGF, FGF, EGF and VEGF) and chemokines (CCL2, CCL3, CCL4, CCL20) [109]. Furthermore, Kotsiou et al. [110] have documented that IL-33/ST2 (suppression of tumorigenicity 2) axis can facilitate EMT process of various cell types and abnormal FB proliferation, ultimately leading to tissue fibrosis. Kawashiri et al. [111] have concluded that increased growth differentiation factor 15 (GDF-15), as a serologic surrogate marker for fibrosis-related processes, may precisely reflect the degree of tissue fibrosis in patients with IgG4-RD.

\subsection{Pathogenic Roles of B Cell Subsets, B Cell-derived Factors and Help Signals in the Tissue Fibrosis of Patients with IgG4-RD}

It is postulated that B lymphocytes and their lineages, Breg's, participate in tissue fibrosis of IgG4-RD. In an in vitro study, Francois et al. [112], by co-culturing peripheral blood B cells and dermal FBs isolated from systemic sclerosis patients, have found an increase in IL-6, TGF- $\beta 1$, CCL2, collagen synthesis, $\alpha$-SMA, TIMP and MMP-9 in dermal FBs. This enhancement can be further augmented by the addition of B cell-activating factor of TNF family (BAFF). Della-Torre et al. [113] have proved that $B$ cell depletion by therapeutic antibody attenuates serologic biomarkers of fibrosis and MFB activation in patients with IgG4-RD. The same group has further directly demonstrated that $\mathrm{B}$ cells obtained from IgG4-RD patients could produce many different profibrotic molecules including PDGFB for stimulating collagen production from FBs, lysyl oxidase like 2 (LOXL2) for extracellular matrix remodeling and various chemotactic factors (CCL4, CCL5, CCL11) for chemo-attraction and activation of FBs [114]. Puente et al. [115] have even proposed that LOXL2 may become a new target for anti-fibrogenic therapy. Breg, via secretion of regulatory cytokines such as IL-10 and TGF- $\beta$, can contribute to fibrosis [101-103]. It is particularly interesting that the antigen-presenting function of memory B cells can enhance proliferation and maturation of follicular helper $\mathrm{T}_{2}$ cell $\left(\mathrm{T}_{\mathrm{fh} 2}\right)$ to become $\mathrm{CD}^{+}-$and $\mathrm{CD}^{+}$-cytotoxic $\mathrm{T}$ cell (Tc) populations [104]. The two cytotoxic $\mathrm{T}$ cell subpopulations then secrete perforin and granzymes (A and B) to induce apoptosis of non-immune, non-endothelium mesenchymal cells, inflammation and finally fibrosis in IgG4-RD [116]. On the other hand, after receiving help signals from $\mathrm{T}_{\text {fh2 }}$ cells, $\mathrm{B}$ cells mature to $\mathrm{CD} 19^{+}$plasmablasts, which can subsequently produce autoantibodies, proinflammatory cytokine (IL-1 $\beta$ ) and profibrotic cytokines (TGF- $\beta 1$, LOXL2 and PDGFB) to enhance collagen fiber synthesis and deposition driven by FBs and MFBs. All of these $B$ cell-derived factors and help signals hasten tissue inflammation and consequently tissue fibrosis in patients with IgG4-RD. Figure 1 depicts the pathogenic role of B lymphocytes as APC and effector cells in the tissue inflammation and fibrosis of patients with IgG4-related disease. 

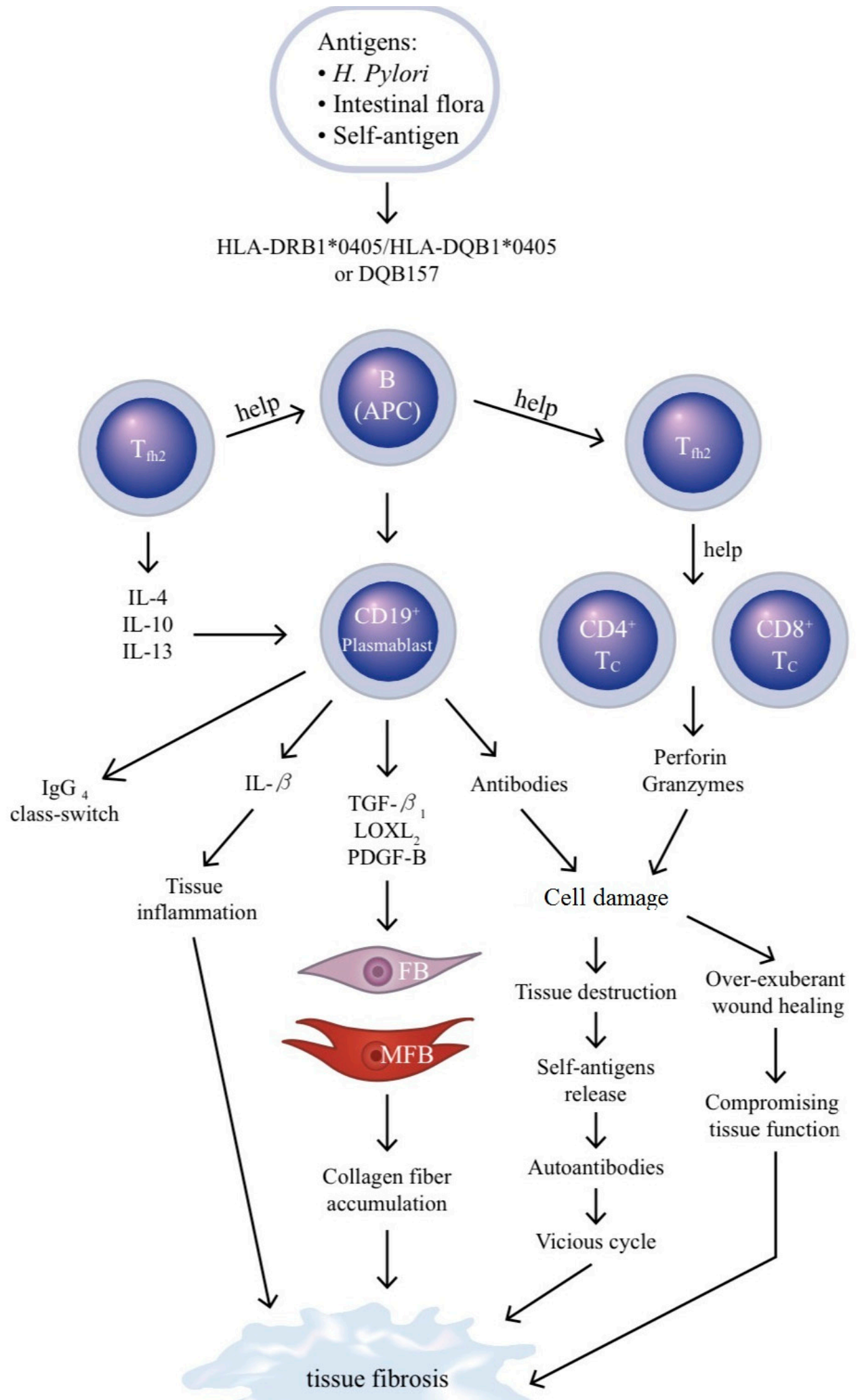

Figure 1. Pathogenic role of the B lymphocyte as antigen-presenting cell (APC) and effector cell in the tissue fibrosis of patients with IgG4-related disease. The genetically predisposed B cells (acting as APCs) bind to environmental offending agents (e.g., H. pylori), intestinal microflora or autoantigens and then provide signals to $\mathrm{CD} 19^{+}$plasmablasts to mediate effector functions including: (1) IgG4 class-switch 
with the help of follicular helper $\mathrm{T} 2\left(\mathrm{~T}_{\mathrm{fh} 2}\right)$, (2) IL-1 $\beta$ production to cause tissue inflammation, (3) production of profibrotic molecules (TGF- $\beta$, LOXL2, PDGF-B) to activate fibroblasts (FBs) and myofibroblasts (MFBs) in charge of collagen fiber production and deposition in the tissue and (4) autoantibody production to contribute to tissue destruction. Moreover, $\mathrm{B}$ cells help $\mathrm{T}_{\mathrm{fh} 2}$ cells facilitate the ontogenetic differentiation of the two cytotoxic T cells (Tc), CD4 ${ }^{+} \mathrm{Tc}$ and CD8 ${ }^{+} \mathrm{Tc}$, in tissue destruction. LOXL2-lysyl oxidase-like 2; PDGF-platelet derived growth factor. For abbreviations not designated here, please see the abbreviation list in the main text.

\section{The Cellular and Molecular Bases of Allergy, Inflammation and Tissue Fibrosis in Patients with IgG4-RD}

In addition to the crucial roles of $\mathrm{B}$ cell subpopulations as antigen-presenting and effector cells in the pathogenesis of tissue fibrosis in patients with IgG4-RD, recent investigations have further revealed that many innate immune cells including white blood cell lineages (neutrophils, basophils and eosinophils), and macrophage type $2(\mathrm{M} 2-\mathrm{M} \varphi)$ /plasmacytoid dendritic cells $(p \mathrm{DC})[117,118]$ and different $\mathrm{T}$ cell subsets including, Th2, Treg, $\mathrm{T}_{\mathrm{fh} 2}$ and $\mathrm{CD} 4^{+}-$and $\mathrm{CD} 8^{+}$-cytotoxic $\mathrm{T}$ cells $\left(\mathrm{CD} 4^{+}\right.$and $\mathrm{CD}^{+} \mathrm{Tc}$ ) play active and critical roles in the immunopathogenesis of IgG4-RD [101].

\subsection{Involvement of Innate Immune Cells in Patients with IgG4-RD}

Triggering of innate immune responses by microbe-associated molecular patterns (MAMPs) and damage-associated molecular patterns (DAMPs) is mediated by binding of these molecules to the TLRs and NOD-like receptors (NLRs) on innate immune cells including $\mathrm{M} \varphi_{2} / p \mathrm{DC}$, basophils and polymorphonuclear cells (PMN). The binding leads to release of proinflammatory cytokines (IL-1 and IL-6), B cell growth factors (BAFF and APRIL) and Th2 differentiation cytokine (IL-4) to induce B cell maturation and Igs class-switch from IgE to IgG4 by modified Th2 response. For clarifying the properties of fibroinflammatory cytokines and their individual producing cells, many authors have successively demonstrated that IL-10 and IL-13 released from Th2, B lymphocyte-activating factor of TNF family (BAFF) and a proliferating inducing ligand (APRIL) released from M2-M $\varphi$ and PMN, IL-4 and IRF-7 released from $p$ DC, IL-33 released from antigen presenting cell (APC) and endothelial cell (EC) in patients with IgG4-RD [117-122]. In addition, activated $\mathrm{M} 2-\mathrm{M} \varphi$ may release profibrotic cytokines (TGF- $\beta$ and IL-33) to activate the production of profibrotic cytokines from Treg including TGF- $\beta$, IL-10 and IL-33. These effects can further stimulate FBs and MFBs to synthesize collagen fibers for storiform fibrosis in IgG4-RD.

\subsection{The Immunopathologic Roles of Aberrant Functions of Treg, $T_{\text {fh }}$ and $C D 4^{+}$and $C D 8^{+} T c$ Subsets in Patients with IgG4-RD}

Recent studies have revealed that increased proportions of Th2 and Treg cells, with their abnormal cytokine production, are involved in IgG4-RD and $\mathrm{CD}^{+} \mathrm{T}$ cell infiltration constitutes the major inflammatory cell populations in IgG4-RD lesions. Tsuboi et al. [123] have detected the mRNA expression of Treg and Th2 cytokines in PBMCs and labial salivary glands by RT-PCR. They have concluded that overexpression of IL-10, TGF- $\beta$ and activation-induced cytidine deaminase (AID) in salivary glands are involved in the pathogenesis of IgG4-RD. Generally, Treg cells are usually subdivided into 2 groups: (1) naturally occurring Treg, with $\mathrm{CD} 45 \mathrm{RO}^{+} \mathrm{CD} 25^{\text {high }} \mathrm{CD} 4^{+}$surface marker and (2) naïve Treg with $\mathrm{CD} 45 \mathrm{RA}^{+} \mathrm{CD} 25^{+} \mathrm{CD} 4^{+}$surface marker. Miyoshi et al. [124] have reported that increased numbers of naturally occurring Treg in the circulation can affect IgG4 production in AIP whereas decreased numbers of naïve Treg may be implicated in the pathogenesis of AIP.

Histologically, ectopic germinal center (GC) formation is present in some lesional tissues of patients with IgG4-RD. Wurster et al. [125] have documented that IL-21 is crucial for Th2 cytokine productions and can specifically inhibit the differentiation of naïve helper T cells to INF- $\gamma$ producing Th1 cells. Furthermore, IL-21 production by $\mathrm{T}_{\mathrm{fh}}$ that expresses CXCR5 (corresponding ligand is CXCL13) chemokine receptor can help GC formation [98]. $\mathrm{T}_{\mathrm{fh}}$ cells are a distinct $\mathrm{CD} 4^{+} \mathrm{T}$ cell subpopulation 
that can expedite B and plasma cell differentiation and finally GC formation. Aberrant expansion and function of $\mathrm{T}_{\mathrm{fh}}$ subsets can be found associated with circulating plasmablast numbers, IgG4, IL-4 levels and tissue damage in patients with IgG4-RD [126,127]. Further investigations by Grados et al. [128] have revealed that IgG4-RD patients showed an increase in circulating Treg, Th17 and $\mathrm{CD} 4^{+} \mathrm{CXCR} 5^{+} \mathrm{PD} 1^{+} \mathrm{T}_{\mathrm{fh}}$ cell populations. The increased $\mathrm{T}_{\mathrm{fh}}$ cells were caused by a specific expansion of $\mathrm{T}_{\mathrm{fh} 2}\left(\mathrm{CCR} 6^{-} \mathrm{CXCR} 3^{-}\right)$, and to a lesser extent, $\mathrm{T}_{\mathrm{fh} 17}\left(\mathrm{CCR} 6^{+} \mathrm{CXCR3}{ }^{-}\right)$subsets. Therefore, IgG4-RD is characterized by a shift of circulating $\mathrm{T}$ cells toward a Th2 $/ \mathrm{T}_{\mathrm{fh} 2}$ and $\mathrm{Th} 17 / \mathrm{T}_{\mathrm{fh} 17}$ polarization.

Although $\mathrm{CD}^{+} \mathrm{T}$ helper cells are regarded as the most abundant cells in the GC of affected tissues in IgG4-RD, these cells are considered as a driver in the pathogenesis of the disease. Another unique $\mathrm{CD} 4^{+} \mathrm{T}$ cells existing in lesional sites are $\mathrm{CD} 4^{+}$cytotoxic $\mathrm{T}$ cells $\left(\mathrm{CD} 4^{+} \mathrm{Tc}\right)$ which secrete cytolytic molecules including perforin and granzymes A and B. Moreover, profibrotic cytokines (IL-1 $\beta$, TGF$\beta)$ and Th1 cytokine (IFN- $\gamma$ ) are also secreted by these cells [129-131]. Some of these unique cells also bear signaling lymphocytic activation molecule F7 (SLAMF7) surface marker which is usually presented on the plasmablasts and plasma cells, but not $\mathrm{CD} 4^{+} \mathrm{T}$ cells [132]. Della-Torre et al. [133] have identified a subset of $\mathrm{CD}^{+}{ }^{+} \mathrm{SLAMF}^{+} \mathrm{CD} 8 \mathrm{a}^{-} \mathrm{T}_{\mathrm{EM}}(\mathrm{CD} 45 \mathrm{RO})$, the cytotoxic $\mathrm{T}$ cells with effector memory phenotype, which is oligoclonally expanded in patients with active IgG4-RD and can be suppressed following glucocorticoid administration to remit disease. In short conclusion, both CD4 ${ }^{+} \mathrm{CTL}$ and $\mathrm{CD}^{+} \mathrm{CTL}$ in disease lesions of IgG4-RD may contribute to the induction of cell apoptosis and tissue fibrosis of the disease [116].

\subsection{Involvement of Abnormally Functioning Bre FliC $g$ Cells in Patients with IgG4-RD}

Kessel et al. [134] have found an antigen-driven B cell with $C D 19^{+} C D 25^{\text {high }}$ surface marker which expresses a regulatory effect to suppress proliferation of autoreactive T lymphocytes. IL-10 is believed to be the major effector molecule released from these Breg cells to exert immune-regulatory functions. Authors have also demonstrated that IL-10 is produced by both $\mathrm{CD} 19^{+} \mathrm{CD} 24^{\text {high }} \mathrm{CD} 27^{+}(\mathrm{B} 10)$ and $\mathrm{CD} 19^{+} \mathrm{CD} 24^{\text {high }} \mathrm{CD} 38^{\text {high }}$ (immature) Breg subsets. Sumimoto et al. [102] and Lin et al. [103] have demonstrated that these two Breg cell aberrations, increased immature Breg subset, but decreased B10 type Breg subset, are involved in IgG4-RD. However, more studies are required to get a definite conclusion. In conjunction with the context of Section 7, we provide a comprehensive scheme to illustrate the cellular and molecular bases of allergy, chronic inflammation, and storiform tissue fibrosis in patients with IgG4-RD in Figure 2. 


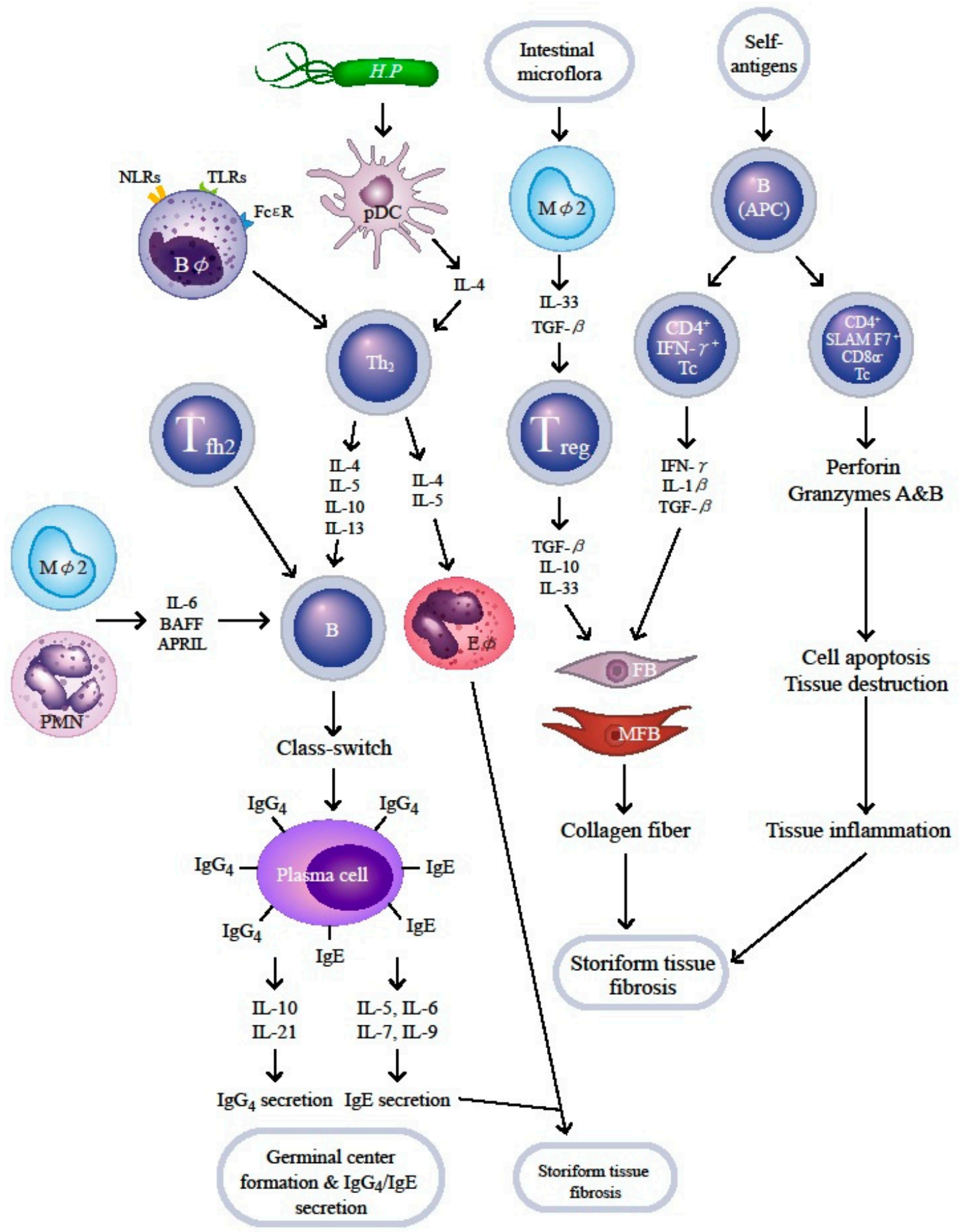

Figure 2. Cellular and molecular bases of immunopathogenesis in patients with IgG4-related disease. The environmental or self-antigens such as PAMP or MAMP bind to the TLRs/NLRs on basophils $(\mathrm{B} \varphi)$ and plasmacytoid dendritic cells $(p D C)$, skewing naïve T cells to Th2 subset. Upon the effects of Treg, $\mathrm{T}_{\mathrm{fh} 2}, \mathrm{M} 2$ macrophage $(\mathrm{M} \varphi 2$,$) and PMN, the B cells mature and undergo Ig class-switch from IgE to$ IgG4 by the modified Th2 response in the ectopic germinal center of fibroinflammatory tissue. The IL-4and IL-5-stimulated eosinophils $(\mathrm{E} \varphi)$ and the residual $\mathrm{IgE}$ mediate allergic reaction. On the other hand, $\mathrm{B}$ cells (as APC), $\mathrm{M} \varphi 2$, and Treg provide profibrotic cytokines to facilitate production and accumulation 
of collagen fibers by fibroblasts (FBs)/myofibroblasts (MFBs) to mediate storiform fibrosis. Furthermore, $\mathrm{B}$ cells as APCs enhance generation of two populations of $\mathrm{CD} 4^{+}$cytotoxic $\mathrm{T}$ cells $\left(\mathrm{CD} 4^{+} \mathrm{Tc}\right)$, $\mathrm{CD} 4^{+} \mathrm{IFN}-\gamma^{+} \mathrm{Tc}$ and $\mathrm{CD} 4^{+} \mathrm{SLAMF} 7^{+} \mathrm{CD} 8 \alpha^{-} \mathrm{Tc}$, to induce cell apoptosis and tissue destruction by the secreted perforin and granzymes (A and B). TLR-Toll-like receptor; NLR-nucleotide-binding oligomerization domain like receptor; Th2-helper T cell type 2; BAFF-B cell-activating factor of tumor necrosis factor family; APRIL—a proliferation-inducing ligand of B cell. For the abbreviations not designated here, please see the abbreviation list in the main text.

\section{Conclusions}

IgG4-RD is a complex, protean and multiorgan fibroinflammatory disease originated from overactive IgG4-producing lymphoplasmacytic cell infiltration in variable tissues. It may thus lead to bizarre clinical and histological manifestations including storiform tissue fibrosis and obliterative phlebitis. The odd properties of IgG4 molecules such as Fab-arm exchange, Fc-Fc aggregation and modified Th2 response lead to immunological paradox in IgG4-RD. A series of florid interactions among innate and adaptive immune cells result in abnormal cytokine/chemokine/growth factor modulation that may lead to fibroinflammatory cell infiltration, tissue inflammation with fibrosis and allergic conditions in patients with IgG4-RD. Many conundrums remain to be solved such as the nature of antigenic stimuli, the molecular mechanism underlying storiform fibrosis, the etiology of aberrant immunobiology, the fine-tuning of genetic/epigenetic modifications of cytokine expression, and the pathologic roles of autoantibodies relevant to immunopathogenesis of IgG4-RD.

\section{Future Prospects}

With regards to the designation of new therapeutic strategies for IgG4-RD other than corticosteroids, nonspecific immunosuppressants and anti-CD20 therapy are mandatory in clinical practice. These strategies may include blockades of modified Th2 response and new anti-fibrogenic therapies. However, many unmet needs should be fulfilled for identifying more in-depth the cellular and molecular mechanisms underlying IgG4-RD—as well as improving its therapies. These investigations may focus on:

1. The precise epigenetic regulations, including DNA methylation/acetylation and histone modifications for the diverse immune dysfunctions in IgG4-RD;

2. The aberrant expression of non-coding RNAs in the ontogenesis of abnormal B cell biology in IgG4-RD;

3. The characterization of factors involved in the induction of $\mathrm{CD}^{4+} \mathrm{Tc}$ in IgG4-RD;

4. The elucidation of the sophisticated molecular mechanism underlying storiform fibrosis;

5. Clarification of the interactions between H. pylori infection and other environmental factors, such as allergens for development of the disease;

6. Immunopathologic roles of different IgG4 autoantibodies in its pathogenesis;

These are only a few points we suggest that may be helpful for understanding IgG4-RD, as well as the unique nature of IgG4, per se. Since the disease is a relatively newly found disorder implicating the humoral immune system, a multi-arrays of work are expected to have fruitful results in the future.

Author Contributions: C.-L.Y. and C.-Y.T. supervised the writing project of the manuscript; C.-Y.T. and S.-C.H. prepared the manuscript and wrote the draft together; H.-T.L. and C.-H.W. prepared the figures and tables; K.-J.L., M.-H.C., C.-Y.S., C.-S.L., Y.-M.K. and H.-C.T. actively participated in the discussions and suggestions for the manuscript. All authors have read and agreed to the published version of the manuscript.

Funding: This research was funded by Ministry of Sciences \& Technology, Executive Yuan (MOST107-2314-B-075-051-MY3) and Taipei Veterans General Hospital (V107C-084), Taiwan.

Acknowledgments: The authors thank all the individuals who participated in this work.

Conflicts of Interest: The authors declare no conflict interest. 


\section{Abbreviations}

AID

AIP

AIT

APC

APRIL

BAFF B

$\mathrm{B} \varphi$

Breg

C

CA

CCL

$\mathrm{CD}$

$\mathrm{CP}$

CTGF

CXCL

CXCR

DAMP

EC

$\mathrm{E} \varphi$

FB

Fc $\gamma \mathrm{R}$

FGFBP2

FliC

GC

GWAS

HLA

H. pylori

IgG4-RD

IFN

IL

IRF-7

$\mathrm{K}$

LF

LOXL2

MAMP

MCRP

MFB

MMP

MST

$\mathrm{M} \varphi$

NLR

$P$

PAMP

PBMC

PBP

$p \mathrm{DC}$

PDGF

PDGFB

PMN

Q

$\mathrm{R}$

RT-PCR activation-induced cytidine deaminase

autoimmune pancreatitis

allergen-induced immunotherapy

antigen presenting cell

a proliferation-inducing ligand

B lymphocyte-activating factor of tumor necrosis factor family basophil

regulatory B lymphocyte

complement component

pancreatic carbonic anhydrase

C-C chemokine motif ligand

cluster of differentiation

chronic pancreatitis

connective tissue growth factor

$\mathrm{C}-\mathrm{X}-\mathrm{C}$ chemokine motif ligand

C-X-C chemokine receptor

damage associated molecular pattern

endothelial cell

eosinophil

fibroblast

Immunoglobulin $\mathrm{G}$ fragment $\mathrm{C}$ gamma receptor

fibroblast growth factor binding protein 2

flagellin

germinal center

genome-wide association study

human leukocyte antigen

Helicobacter pylori

IgG4-related disease

interferon

interleukin

interferon regulatory factor-7

lysine

lactoferrin

lysyl oxidase-like 2

microbe-associated molecular pattern

monomeric $\mathrm{C}$-reactive protein

myofibroblast

matrix metalloproteinase

mammalian STE20-like protein kinase

macrophage

nucleotide-binding oligomerization domain like receptor

proline

pathogen-associated molecular pattern

peripheral blood mononuclear cell

plasminogen-binding protein

plasmacytoid dendritic cell

platelet-derived growth factor

platelet-derived growth factor B

polymorphonuclear neutrophil

glutamine

arginine

reverse transcriptase assisted polymerase chain reaction 


$\begin{array}{ll}\text { S } & \text { serine } \\ \text { SIPS } & \text { systemic IgG4-related plasmacytic syndrome } \\ \text { SLAMF7 } & \text { signaling lymphocytic activation molecule F7 } \\ \text { SLE } & \text { systemic lupus erythematosus } \\ \text { SNP } & \text { single nucleotide polymorphism } \\ \text { SPINK1 } & \text { serine peptidase inhibitor, Kazal type 1 } \\ \text { PST1 } & \text { pancreatic secretary trypsin inhibitor-1 } \\ \text { PRSS1 } & \text { protease serine 1 (trypsin 1) } \\ \text { ST2 } & \text { suppression of tumorigenicity 2 } \\ \text { Tc } & \text { cytotoxic T lymphocyte } \\ \text { TCN1 } & \text { transcobalamin 1 } \\ \text { T } & \text { T cells with effector memory phenotype } \\ T_{\text {fh }} & \text { follicular helper T cell } \\ \text { TGF } & \text { transforming growth factor } \\ \text { Th } & \text { helper T lymphocyte } \\ \text { TIMP } & \text { tissue inhibitor of matrix metalloproteinase } \\ \text { TLR } & \text { Toll-like receptor } \\ \text { Treg } & \text { regulatory T lymphocyte } \\ \text { UBR2 } & \text { ubiquitin-protein ligase E3 component n-region 2 }\end{array}$

\section{References}

1. Kamisawa, T.; Zen, Y.; Pillai, S.; Stone, J.H. IgG4-related disease. Lancet 2015, 385, 1460-1471. [CrossRef]

2. Yadlapati, S.; Verheyen, E.; Efthimiou, P. IgG4-related disease: A complex under-diagnosed clinical entity. Rheumatol. Int. 2018, 38, 169-177. [CrossRef] [PubMed]

3. Okazaki, K.; Uchida, K. Current prospectives on autoimmune pancreatitis and IgG4-related disease. Proc. Jpn. Acad. Ser. B Phys. Biol. Sci. 2018, 94, 412-418. [CrossRef] [PubMed]

4. Maehara, T.; Moriyama, M.; Nakamura, S. Review of a novel disease entity, immunoglobulin G4-related disease. J. Korean Assoc. Oral Maxillofac. Surg. 2020, 46, 3-11. [CrossRef]

5. Mahajan, V.S.; Mattoo, H.; Deshpande, V.; Pillai, S.S.; Stone, J.H. IgG4-related disease. Annu. Rev. Pathol. Mech. Dis. 2014, 9, 315-347. [CrossRef]

6. Stone, J.H.; Khosroshahi, A.; Deshpande, V.; Chan, J.K.C.; Heathcote, J.G.; Aalberse, R.; Azumi, A.; Bloch, D.B.; Brugge, W.R.; Carruthers, M.N.; et al. Recommendations for the nomenclature of IgG4-related disease and its individual organ system manifestations. Arthritis Rheum. 2012, 64, 3061-3067. [CrossRef]

7. Umehara, H.; Okazaki, K.; Masaki, Y.; Kawano, M.; Yamamoto, M.; Saeki, T.; Matsui, S.; Sumida, T.; Mimori, T.; Tanaka, Y.; et al. A novel clinical entity, IgG4-related disease (IgG4RD): General concept and detail. Mod. Rheumatol. 2012, 22, 1-14. [CrossRef]

8. Della-Torre, E.; Mattoo, H.; Mahajan, V.S.; Deshpande, V.; Krause, D.; Song, P.; Pillai, S.; Stone, J.H. IgG4-related midline destructive lesion. Ann. Rheum. Dis. 2014, 73, 1434-1436. [CrossRef]

9. Okazaki, K.; Tomiyama, T.; Mitsuyama, T.; Sumimoto, K.; Uchida, K. Diagnosis and classification of autoimmune pancreatitis. Autoimmun. Rev. 2014, 13, 451-458. [CrossRef]

10. Zen, Y.; Nakanuma, Y. IgG4-related disease: A cross-sectional study of 114 cases. Am. J. Surg. Pathol. 2010, 34, 1812-1819. [CrossRef]

11. Deshpande, V.; Zen, Y.; Chan, J.K.C.; Yi, E.E.; Sato, Y.; Yoshino, T.; Klöppel, G.; Heathcote, J.G.; Khosroshahi, A.; Ferry, J.A.; et al. Consensus statement on the pathology of IgG4-related disease. Mod. Pathol. 2012, 25, 1181-1192. [CrossRef] [PubMed]

12. Bledsoe, J.R.; Della-Torre, E.; Rovati, L.; Deshpande, V. IgG4-related disease: Review of the histopathologic features, differential diagnosis, and therapeutic approach. APMIS 2018, 126, 459-476. [CrossRef]

13. Wallace, Z.S.; Naden, R.P.; Chari, S.; Choi, H.K.; Della-Torre, E.; Dicaire, J.-F.; Hart, P.A.; Inoue, D.; Kawano, M.; Khosrashahi, A.; et al. The 2019 American College of Rheumatology/European League Against Rheumatism classification criteria for IgG4 related disease. Ann. Rheum. Dis. 2019, 79, 77-87. [CrossRef] [PubMed]

14. Oguchi, T.; Ota, M.; Ito, T.; Hamano, H.; Arakura, N.; Katsuyama, Y.; Meguro, A.; Kawa, S. Investigation of susceptibility genes triggering lacrimal/salivary gland lesion complications in Japanese patients with type 1 autoimmune pancreatitis. PLOS ONE 2015, 10. [CrossRef] [PubMed] 
15. Qin, F.; Tian, J.; Zhou, D.; Chen, L. Mst1 and Mst2 kinases: Regulations and diseases. Cell Biosci. 2013 , 3, 31. [CrossRef]

16. Siedel, C.; Schagdarsurengin, U.; Blumke, K.; Würl, P.; Pfeifer, G.P.; Hauptmann, S.; Taubert, H.; Dammann, R. Frequent hypermethylation of MST1 and MST2 in soft tissue sarcoma. Mol. Carcinog. 2007, 46, 865-871. [CrossRef]

17. Fukuhara, T.; Tomiyama, T.; Yasuda, K.; Ueda, Y.; Ozaki, Y.; Son, Y.; Nomura, S.; Uchida, K.; Okazaki, K.; Kinashi, T. Hypermethylation of MST1 in IgG4-related autoimmune pancreatitis and rheumatoid arthritis. Biochem. Biophys. Res. Commun. 2015, 463, 968-974. [CrossRef] [PubMed]

18. Abuharbeid, S.; Czubayko, F.; Aigner, A. The fibroblasts growth factor-binding protein FGF-BP. Int. J. Biochem. Cell Biol. 2006, 38, 1463-1468. [CrossRef]

19. Newman, J.H.; Shaver, A.; Sheehan, J.H.; Mallal, S.; Stone, J.H.; Pillai, S.; Bastarache, L.; Riebau, D.; Allard-Chamard, H.; Stone, W.M.; et al. IgG4-related disease: Association with a rare gene variant expression in cytotoxic T cells. Mol. Genet. Genomic Med. 2019, 7, e686. [CrossRef]

20. Haruta, I.; Yanagisawa, N.; Kawamura, S.; Fukukawa, T.; Shimizu, K.; Kato, H.; Kobayashi, M.; Shiratori, K.; Yagi, J. A mouse model of autoimmune pancreatitis with salivary gland involvement triggered by innate immunity via persistent exposure to avirulent bacteria. Lab. Invest. 2010, 90, 1757-1769. [CrossRef]

21. Yanagisawa, N.; Haruta, I.; Shimizu, K.; Fukukawa, T.; Higuchi, T.; Shibata, N.; Shiratori, K.; Yagi, J. Identification of commensal flora-associated antigen as a pathogenetic factor of autoimmune pancreatitis. Pancreatology 2014, 14, 100-106. [CrossRef] [PubMed]

22. Akitake, R.; Watanabe, T.; Zaima, C.; Uza, N.; Ida, H.; Tada, S.; Nishida, N.; Chiba, T. Possible involvement of T helper type 2 responses to Toll-like receptor ligands in IgG4-related sclerosing disease. Gut 2010, 59, 542-545. [CrossRef] [PubMed]

23. Watanabe, T.; Yamashita, K.; Fujikawa, S.; Sakurai, T.; Kudo, M.; Shiokawa, M.; Kodama, Y.; Uchida, K.; Okazaki, K.; Chiba, T. Involvement of activation of Toll-like receptors and nucleotide-binding oligomerization domain-like receptors in enhanced IgG4 responses in autoimmune pancreatitis. Arthritis Rheum. 2012, 64, 914-924. [CrossRef] [PubMed]

24. Watanabe, T.; Yamashita, K.; Sakurai, T.; Kudo, M.; Shiokawa, M.; Uza, N.; Kodama, Y.; Uchida, K.; Okazaki, K.; Chiba, T. Toll-like receptor activation in basophils contributes to the development of IgG4-related disease. J. Gastroenterol. 2013, 48, 247-253. [CrossRef]

25. Suurmond, J.; Stoop, J.N.; Rivellese, F.; Bakker, A.M.; Huizinga, T.W.J.; Toes, R.E.M. Activation of human basophils by combined Toll-like receptor- and FceRI-triggering can promote Th2 skewing of naïve T helper cells. Eur. J. Immunol. 2014, 44, 386-396. [CrossRef]

26. Yanagawa, M.; Uchida, K.; Ando, Y.; Tomiyama, T.; Yamaguchi, T.; Ikeura, T.; Fukui, T.; Nishio, A.; Uemura, Y.; Miyara, T.; et al. Basophils activated via TLR signaling may contribute to pathophysiology of type 1 autoimmune pancreatitis. J. Gastroenterol. 2018, 53, 449-460. [CrossRef]

27. Ahuja, M.; Schwartz, D.M.; Tandon, M.; Son, A.; Zeng, M.; Swaim, W.; Eckhaus, M.; Hoffman, V.; Cui, Y.; Xiao, B.; et al. Orai 1-mediated antimicrobial secretion from pancreatic acini shapes the gut microbiome and regulates gut innate immunity. Cell Metab. 2017, 25, 635-646. [CrossRef]

28. Hamada, S.; Masamune, A.; Nabeshima, T.; Shimosegawa, T. Differences in gut microbiota profiles between autoimmune pancreatitis and chronic pancreatitis. Tohoku J. Exp. Med. 2018, 244, 113-117. [CrossRef]

29. Kamata, K.; Watanabe, T.; Minaga, K.; Hara, A.; Yoshikawa, T.; Okamoto, A.; Yamao, K.; Takenaka, M.; Park, A.-M.; Kudo, M. Intestinal dysbiosis mediates experimental autoimmune pancreatitis via activation of plasmacytoid dendritic cells. Int. Immunol. 2019, 31, 795-809. [CrossRef]

30. Deutsch, H.F. Carbonic anhydrases. Int. J. Biochem. 1987, 19, 101-113. [CrossRef]

31. Inagaki, Y.; Jinno-Yoshida, Y.; Hamasaki, Y.; Ueki, H. A novel autoantibody reactive with carbonic anhydrase in sera from patients with systemic lupus erythematosus and Sjögren's syndrome. J. Dermatol. Sci. 1991, 2, 147-154. [CrossRef]

32. Nishimori, I.; Bratanova, T.; Toshkov, I.; Caffrey, T.; Mogaki, M.; Shibata, Y.; Hollingsworth, M.A. Induction of experimental autoimmune sialoadenitis by immunization of $\mathrm{PL} / \mathrm{j}$ mice with carbonic anhydrase II. J. Immunol. 1995, 154, 4865-4873. [PubMed]

33. Kino-Ohsaki, J.; Nishimori, I.; Morita, M.; Okazaki, K.; Yamamoto, Y.; Onishi, S.; Hollingsworth, M.A. Serum antibodies to carbonic anhydrase I and II in patients with idiopathic chronic pancreatitis and Sjogren's syndrome. Gastroenterology 1996, 110, 1579-1586. [CrossRef] [PubMed] 
34. Okazaki, K.; Uchida, K.; Ohana, M.; Nakase, H.; Uose, S.; Inai, M.; Matsushima, Y.; Katamura, K.; Ohmori, K.; Chiba, T. Autoimmune-related pancreatitis is associated with autoantibodies and a Th1/Th2-type cellular immune response. Gastroenterology 2000, 118, 573-581. [CrossRef]

35. Aparisi, L.; Farre, A.; Gomez-Cambronero, L.; Martinez, J.; De Las Heras, G.; Corts, J.; Navarro, S.; Mora, J.; Lopez-Hoyos, M.; Sabater, L.; et al. Antibodies to carbonic anhydrase and IgG4 levels in idiopathic chronic pancreatitis: Relevance for diagnosis of autoimmune pancreatitis. Gut 2005, 54, 703-709. [CrossRef] [PubMed]

36. Nishimori, I.; Miyaji, E.; Morimoto, K.; Nagao, K.; Kamada, M.; Onishi, S. Serum antibodies to carbonic anhydrase IV in patients with autoimmune pancreatitis. Gut 2005, 54, 274-281. [CrossRef] [PubMed]

37. Asada, M.; Nishio, A.; Uchida, K.; Kido, M.; Ueno, S.; Uza, N.; Kiriya, K.; Inoue, S.; Kitamura, H.; Ohashi, S.; et al. Identification of a novel autoantibody against pancreatic secretory trypsin inhibitor in patients with autoimmune pancreatitis. Pancreas 2006, 33, 20-26. [CrossRef]

38. Frulloni, L.; Lunardi, C.; Simone, R.; Dolcino, M.; Scattolini, C.; Falconi, M.; Benini, L.; Vantini, I.; Corrocher, R.; Puccetti, A. Identification of a novel antibody associated with autoimmune pancreatitis. N. Engl. J. Med. 2009, 361, 2135-2142. [CrossRef]

39. Löhr, J.-M.; Faissner, R.; Koczan, D.; Bewerunge, P.; Bassi, C.; Brors, B.; Eils, R.; Frulloni, L.; Funk, A.; Halangk, W.; et al. Autoantibodies against the exocrine pancreas in autoimmune pancreatitis: Gene and protein expression profiling and immunoassays identify pancreatic enzymes as a major target of the inflammatory process. Am. J. Gastroenterol. 2010, 105, 2060-2071.

40. Yamamoto, M.; Naishiro, Y.; Suzuki, C.; Kodai, Y.; Suzuki, R.; Honda, S.; Abe, T.; Takahashi, H.; Shinomura, Y. Proteomics analysis in 28 patients with systemic IgG4-related plasmacytic syndrome. Rheumatol. Int. 2010, 30, 565-568. [CrossRef]

41. Castañón, M.S.; Zuliani, V.; Amodio, A.; Campagnola, P.; Granato, A.; Gabbrielli, A.; Benini, L.; Hoyos, M.L.; Frulloni, L. Role of amylase-2A autoantibodies in the diagnosis of autoimmune pancreatitis. Pancreas 2015, 44, 1078-1082. [CrossRef] [PubMed]

42. Du, H.; Shi, L.; Chen, P.; Yang, W.; Xun, Y.; Yang, C.; Zhao, L.; Zhou, Y.; Chen, G. Prohibitin is involved in patients with IgG4 related disease. PLoS ONE 2015. [CrossRef] [PubMed]

43. Liu, H.; Perugino, C.A.; Ghebremichael, M.; Wallace, Z.S.; Montesi, S.B.; Stone, J.H.; Pillai, S. Disease severity linked to increase in autoantibody diversity in IgG4-related disease. Arthritis Rheumatol. 2020, 72, 687-693. [CrossRef]

44. Salah, A.; Yoshifuji, H.; Ito, S.; Kitagori, K.; Kiso, K.; Yamada, N.; Nakajima, T.; Haga, H.; Tsuruyama, T.; Miyagawa-Hayashino, A. High expression of galectin-3 in patients with IgG4-related disease: A proteomic approach. Pathol. Res. Int. 2017, 2017. [CrossRef] [PubMed]

45. Perugino, C.A.; Al Salem, S.B.; Mattoo, H.; Della-Torre, E.; Mahajan, V.; Ganesh, G.; Allard-Chamard, H.; Wallace, Z.; Montesi, S.B.; Kreuzer, J.; et al. Identification of galectin-3 as an auto-antigen in patients with IgG4-related disease. J. Allergy Clin. Immunol. 2019, 143, 736-745. [CrossRef]

46. Hubers, L.M.; Vos, H.; Schuurman, A.R.; Erken, R.; Oude Elferink, R.P.; Burgering, B.; van de Graaf, S.F.J.; Beuers, U. Annexin $\mathrm{A}_{11}$ is targeted by IgG4 and IgG1 autoantibodies in IgG4-related disease. Gut 2018, 67, 728-735. [CrossRef]

47. Shiokawa, M.; Kodama, Y.; Sekiguchi, K.; Kuwada, T.; Tomono, T.; Kuriyama, K.; Yamazaki, H.; Morita, T.; Marui, S.; Sogabe, Y.; et al. Laminin 511 is a target antigen in autoimmune pancreatitis. Sci. Transl. Med. 2018, 10. [CrossRef]

48. Pu, L.; Zhang, P.; Li, G. IgG4-related acute interstitial nephritis and the potential role of mCRP autoantibodies: A case report. Renal Fail. 2019, 41, 657-661. [CrossRef]

49. Aoki, S.; Nakazawa, T.; Ohara, H.; Sano, H.; Nakao, H.; Joh, T.; Murase, T.; Eimoto, T.; Itoh, M. Immunohistochemical study of autoimmune pancreatitis using anti-IgG4 antibody and patients' sera. Histopathology 2005, 47, 147-158. [CrossRef]

50. Shiokawa, M.; Kodama, Y.; Kuriyama, K.; Yoshimura, K.; Tomono, T.; Morita, T.; Kakiuchi, N.; Matsumori, T.; Mima, A.; Nishikawa, Y.; et al. Pathogenicity of IgG in patients with IgG4-related disease. Gut 2016, 65, 1322-1332. [CrossRef]

51. Aalberse, R.C.; Stapel, S.O.; Schuurman, J.; Rispens, T. Immunoglobulin G4: An odd antibody. Clin. Exp. Allergy 2009, 39, 469-477. [CrossRef] [PubMed] 
52. Punnonen, J.; Aversa, G.; Cocks, B.G.; McKenzie, A.N.; Menon, S.; Zurauski, G.; de Waal Malefyt, R.; de Vries, J.E. Interleukin 13 induces interleukin 4-independent IgG4 and IgE synthesis and CD23 expression by human B cells. Proc. Natl. Acad. Sci. USA 1993, 90, 3730-3734. [CrossRef] [PubMed]

53. Aalberse, R.C.; van der Gaag, R.; van Leeuwen, J. Serologic aspects of IgG4 antibodies. I. prolonged immunization results in an IgG4-restricted response. J Immunol. 1983, 130, 722-726. [PubMed]

54. Platts-Mills, T.; Vaughan, J.; Squillace, S.; Woodfolk, J.; Sporik, R. Sensitisation, asthma, and a modified $\mathrm{T}_{\mathrm{h} 2}$ response in children exposed to cat allergen: A population-based cross-sectional study. Lancet 2001, 357, 752-756. [CrossRef]

55. Aalberse, R.C.; Platts-Mills, T.A.; Rispens, T. The developmental history of IgE and IgG4 antibodies in relation to atopy, eosinophilic esophagitis, and the modified TH2 response. Curr. Allergy Asthma Rep. 2016, 16, 45. [CrossRef]

56. Jeannin, P.; Lecoanet, S.; Delneste, Y.; Gauchat, J.F.; Bonnefoy, J.Y. IgE versus IgG4 production can be differentially regulated by IL-10. J. Immunol. 1998, 160, 3555-3561.

57. Van der Neut Kolfschoten, M.; Schuurman, J.; Losen, M.; Bleeker, W.K.; Martínez-Martínez, P.; Vermeulen, E.; den Bleker, T.H.; Wiegman, L.; Vink, T.; Aarden, L.A.; et al. Anti-inflammatory activity of human IgG4 antibodies by dynamic Fab-arm exchange. Science 2007, 317, 1554-1557. [CrossRef]

58. Wood, N.; Bourque, K.; Donaldson, D.D.; Collins, M.; Vercelli, D.; Goldman, S.J.; Kasaian, M.T. IL-21 effects on human IgE production in response to IL-4 or IL-13. Cell Immunol. 2004, 231, 133-145. [CrossRef]

59. Avery, D.T.; Bryant, V.L.; Ma, C.S.; de Waal Malefyt, R.; Tangye, S.G. IL-21-induced isotype switching to IgG and IgA by human naïve B cells is differentially regulated by IL-4. J. Immunol. 2008, 181, 1767-1779. [CrossRef]

60. Akiyama, M.; Yasuoka, H.; Yoshimoto, K.; Takeuchi, T. Interleukin-4 contributes to the shift of balance of IgG subclasses toward IgG4 in IgG4-related disease. Cytokine 2018, 110, 416-419. [CrossRef]

61. Van der Zee, J.S.; van Swieten, P.; Aalberse, R.C. Serological aspects of IgG4 antibodies. II. IgG4 antibodies form small nonprecipitating immune complexes due to functional monovalency. J. Immunol. 1986, 137, 3566-3571.

62. Van der Zee, J.S.; van Swieten, P.; Aalberse, R.C. Inhibition of complement activation by IgG4 antibodies. Clin. Exp. Immunol. 1986, 64, 415-422. [PubMed]

63. Lei, D.K.; Saltoun, C. Allergen immunotherapy: Definition indications, and reactions. Allergy Asthma Proc. 2019, 40, 369-371. [CrossRef] [PubMed]

64. Sutton, B.J.; Davies, A.M.; Bax, H.J.; Karagiannis, S.N. IgE antibodies: From structure to function and clinical translation. Antibodies 2019, 8, 19. [CrossRef] [PubMed]

65. Jiang, X.-R.; Song, A.; Bergelson, S.; Arroll, T.; Parekh, B.; May, K.; Chung, S.; Strouse, R.; Mire-Sluis, A.; Schenerman, M. Advances in the assessment and control of the effector functions of therapeutic antibodies. Nat. Rev. Drug Discov. 2011, 10, 101-111. [CrossRef] [PubMed]

66. Herbener, P.; Schönfeld, K.; König, M.; Germer, M.; Przyborski, J.M.; Bernöster, K.; Schüttrumpf, J. Functional relevance of in vivo half antibody exchange of an IgG4 therapeutic antibody-drug conjugate. PLoS ONE 2018, 13. [CrossRef]

67. Aalberse, R.C.; Schuurman, J. IgG4 breaking the rules. Immunology 2002, 105, 9-19. [CrossRef]

68. Schuurman, J.; van Ree, R.; Perdok, G.J.; van Doom, H.R.; Tan, K.Y.; Aalberse, R.C. Normal human immunoglobulin G4 is bispecific: It has two different antigen-combining sites. Immunology 1999, 97, 693-698. [CrossRef]

69. Davies, A.M.; Rispens, T.; Ooijevaar-de Heer, P.; Gould, H.J.; Jefferis, R.; Aalberse, R.C.; Sutton, B.J. Structural determinants of unique properties of human IgG4-Fc. J. Mol. Biol. 2014, 426, 630-644. [CrossRef]

70. Rispens, T.; Qoijevaar-de Heer, P.; Bende, O.; Aablerse, R.C. Mechanism of immunoglobulin G4 Fab-arm exchange. J. Am. Chem. Soc. 2011, 133, 10302-10311. [CrossRef]

71. Davies, A.M.; Sutton, B.J. Human IgG4: A structural perspective. Immunol. Rev. 2015, 268, 139-159. [CrossRef] [PubMed]

72. Trampert, D.C.; Hubers, L.M.; van de Graaf, S.F.J.; Beuers, U. On the role of IgG4 in inflammatory conditions: Lessons for IgG4-related disease. Biochim. Biophys. Acta Mol. Basis Dis. 2018, 1864, 1401-1409. [CrossRef] [PubMed]

73. Liu, M.; Hao, M. Unique properties of IgG4 antibody and its clinical application in autoimmune pancreatitis. Scand. J. Gastroenterol. 2018, 53, 1121-1131. [CrossRef] [PubMed] 
74. Tao, M.-H.; Smith, R.I.; Morrison, S.L. Structural features of human immunoglobulin G that determine isotype-specific differences in complement activation. J. Exp. Med. 1993, 178, 661-667. [CrossRef] [PubMed]

75. Zack, D.J.; Stempniak, M.; Wong, A.L.; Weisbart, R.H. Localization of an Fc-binding reactivity to the constant region of human IgG4.Implications for the pathogenesis of rheumatoid arthritis. J. Immunol. 1995, 155, 5057-5063. [PubMed]

76. Rock, B.; Martins, C.R.; Theofilopoulos, A.N.; Balderas, R.S.; Anhalt, G.J.; Labib, R.S.; Futamura, S.; Rivitti, E.A.; Diaz, L.A. The pathogenic effect of IgG4 autoantibodies in endemic pemphigus foliaceus (Fogo Selvagem). N. Engl. J. Med. 1989, 320, 1463-1469. [CrossRef]

77. Huijbers, M.G.; Querol, L.A.; Niks, E.H.; Plomp, J.J.; van der Maarel, S.M.; Graus, F.; Dalmau, J.; Illa, I.; Verschuuren, J.J. The expanding field of IgG4-mediated neurological autoimmune disorders. Eur. J. Neurol. 2015, 22, 1151-1161. [CrossRef]

78. Liu, L.; Chang, B.; Wu, X.; Guo, Y.; Pan, Y.; Yang, L. Expression of phospholipase A2 receptor and IgG4 in patients with membranous nephropathy. Vasc. Health Risk Manag. 2018, 14, 103-108. [CrossRef]

79. Huijbers, M.G.; Plomp, J.J.; van der Maarel, S.M.; Verschuuren, J.J. IgG4-mediated autoimmune diseases: A niche of antibody-mediated disorders. Ann. N.Y. Acad. Sci. 2018, 1413, 92-103. [CrossRef]

80. Kawano, M.; Saeki, T.; Nakashima, H.; Nishi, S.; Yamaguchi, Y.; Hisano, S.; Yamanaka, N.; Inoue, D.; Yamamoto, M.; Takahashi, H.; et al. Proposal for diagnostic criteria for IgG4-related kidney disease. Clin. Exp. Nephrol. 2011, 15, 615-626. [CrossRef]

81. Muraki, T.; Hamano, H.; Ochi, Y.; Komatsu, K.; Komiyama, Y.; Arakura, N.; Yoshizawa, K.; Ota, M.; Kawa, S.; Kiyosawa, K. Autoimmune pancreatitis and complement activation system. Pancreas 2006, 32, 16-21. [CrossRef] [PubMed]

82. Deshpande, V.; Chicano, S.; Finkelberg, D.; Selig, M.K.; Mino-Kenudson, M.; Brugge, W.R.; Colvin, R.B.; Lauwers, G.Y. Autoimmune pancreatitis: A systemic immune complex mediated disease. Am. J. Surg. Pathol. 2006, 30, 1537-1545. [CrossRef] [PubMed]

83. Cornell, L.D.; Chicano, S.L.; Deshpande, V.; Collins, A.B.; Selig, M.K.; Lauwers, G.Y.; Barisoni, L.; Colvin, R.B. Pseudotumors due to IgG4 immune-complex tubulointerstitial nephritis associated with autoimmune pancreatocentric disease. Am. J. Surg. Pathol. 2007, 31, 1586-1597. [CrossRef]

84. Sugimoto, M.; Watanabe, H.; Asano, T.; Sato, S.; Takagi, T.; Kobayashi, H.; Ohira, H. Possible participation of IgG4 in the activation of complement in IgG4-related disease with hypocomplementemia. Mod. Rheumatol. 2016, 26, 251-258. [CrossRef] [PubMed]

85. Konno, N.; Sugimoto, M.; Takagi, T.; Furuya, M.; Asano, T.; Sato, S.; Kobayashi, H.; Migita, K.; Miura, Y.; Aihara, T.; et al. Changes in N-glycans of IgG4 and its relationship with the existence of hypocomplementemia and individual organ involvement in patients with IgG4- related disease. PLoS ONE 2018, 13, e0196163. [CrossRef] [PubMed]

86. Culver, E.L.; van de Bovenkamp, F.S.; Derksen, N.I.L.; Koers, J.; Cargill, T.; Barnes, E.; de Neef, L.A.; Koeleman, C.A.M.; Aelberse, R.C.; Wuhrer, M.; et al. Unique patterns of glycosylation in immunoglobulin subclass G4-related disease and primary sclerosing cholangitis. J. Gastroenterol. Hepatol. 2019, 34, 1878-1886. [CrossRef] [PubMed]

87. Kamisawa, T.; Anjiki, H.; Egawa, N.; Kubota, N. Allergic manifestations in autoimmune pancreatitis. Eur. J. Gastroenterol. Hepatol. 2009, 21, 1136-1139. [CrossRef]

88. Van Toorenenbergen, A.W.; van Heerde, M.J.; van Buuren, H.R. Potential value of serum total IgE for differentiation between autoimmune pancreatitis and pancreatic cancer. Scand. J. Immunol. 2010, 72, 444-448. [CrossRef]

89. Zhang, L.; Guo, L.; Huang, Y.; Wang, T.; Shi, X.; Chang, H.; Yao, W.; Huang, X. Allergic diseases, immunoglobulin E, and autoimmune pancreatitis: A retrospective study of 22 patients. Chin. Med. J. 2014, 127, 4104-4109.

90. Della-Torre, E.; Mattoo, H.; Mahajan, V.S.; Carruthers, M.; Pillai, S.; Stone, J.H. Prevalence of atopy, eosinophilia, and IgE elevation in IgG4-related disease. Allergy 2014, 69, 269-272. [CrossRef]

91. Punnonen, J.; de Waal Malefyt, R.; van Vlasselaer, P.; Gauchat, J.F.; de Vries, J.E. IL-10 and viral IL-10 prevent IL-4-induced IgE synthesis by inhibiting the accessory cell function of monocytes. J. Immunol. 1993, 151, 1280-1289.

92. Lin, A.A.; Freeman, A.F.; Nutman, T.B. IL-10 indirectly downregulates IL-4-induced IgE production by human B cells. Immunohorizons 2018, 2, 398-406. [CrossRef] 
93. Schülke, S. Induction of interleukin-10 producing dendritic cells as a tool to suppress allergen-specific $\mathrm{T}$ helper 2 responses. Front. Immunol. 2018, 9, 455. [CrossRef]

94. Saeki, T.; Kobayashi, D.; Ito, T.; Tamura, M.; Yoshikawa, S.; Yamazaki, H. Comparison of clinical and laboratory features of patients with and without allergic conditions in IgG4-related disease: A single-center experience in Japan. Mod. Rheumatol. 2018, 28, 845-848. [CrossRef] [PubMed]

95. Culver, E.L.; Sadler, R.; Bateman, A.C.; Makuch, M.; Cargill, T.; Ferry, B.; Aalberse, R.; Barnes, E.; Rispens, T. Increases in IgE, eosinophils, and mast cells can be used in diagnosis and to predict relapse of IgG4-related disease. Clin. Gastroenterol. Hepatol. 2017, 15, 1444-1452. [CrossRef]

96. Della-Torre, E.; Germanò, T.; Ramirez, G.A.; Dagna, L.; Yacoub, M.R. IgG4-related disease and allergen-specific immunotherapy. Ann. Allergy Asthma Immunol. 2020, 124, 631-633. [CrossRef]

97. Touzani, F.; Pozdzik, A. New insights into immune cells cross-talk during IgG4-related disease. Clin. Immunol. 2019, 198, 1-10. [CrossRef] [PubMed]

98. Maehara, T.; Moriyama, M.; Nakashima, H.; Miyake, K.; Hayashida, J.-N.; Tanaka, A.; Shinozaki, S.; Kubo, Y.; Nakamura, S. Interleukin-21 contributes to germinal center formation and immunoglobulin G4 production in IgG4-related dacryoadenitis and sialoadenitis, so-called Mikulicz's disease. Ann. Rheum. Dis. 2012, 71, 2011-2019. [CrossRef]

99. Lin, W.; Zhang, P.; Chen, H.; Chen, Y.; Yang, H.; Zheng, W.; Zhang, X.; Zhang, F.; Zhang, W.; Lipsky, P.E. Circulating plasmablasts/plasma cells: A potential biomarker for IgG4-related disease. Arthritis Res. Ther. 2017, 19, 25. [CrossRef] [PubMed]

100. Carruthers, M.N.; Topazian, M.D.; Khosroshahi, A.; Witzig, T.E.; Wallace, Z.S.; Hart, P.A.; Deshpande, V.; Smyrk, T.C.; Chari, S.; Stone, J.H. Rituximab for IgG4-related disease: A prospective, open-label trial. Ann. Rheum. Dis. 2015, 74, 1171-1177. [CrossRef]

101. Xiao, X.; Lian, M.; Zhang, W.; Gershwin, M.E.; Ma, X. The immunologic paradoxes of IgG4-related disease. Clin. Rev. Allergy Immunol. 2018, 54, 344-351. [CrossRef]

102. Sumimoto, K.; Uchida, K.; Kusuda, T.; Mitsuyama, T.; Sakaguchi, Y.; Fukui, T.; Matushita, M.; Takaoka, M.; Nishio, A.; Okazaki, K. The role of $\mathrm{CD} 19^{+} \mathrm{CD} 24^{\text {high }} \mathrm{CD} 38^{\text {high }}$ and $\mathrm{CD} 19^{+} \mathrm{CD} 24^{\text {high }} \mathrm{CD} 27^{+}$regulatory B cells in patients with type 1 autoimmune pancreatitis. Pancreatology 2014, 14, 193-200. [CrossRef]

103. Lin, W.; Jin, L.; Chen, H.; Wu, Q.; Fei, Y.; Zheng, W.; Wang, Q.; Li, P.; Li, Y.; Zhang, W.; et al. B cell subsets and dysfunction of regulatory B cells in IgG4-related diseases and primary Sjögren's syndrome: The similarities and differences. Arthritis Res. Ther. 2014, 16, R118. [CrossRef] [PubMed]

104. Hofmann, K.; Clauder, A.-K.; Manz, R.A. Targeting B cells and plasma cells in autoimmune diseases. Front. Immunol. 2018, 9, 835. [CrossRef] [PubMed]

105. Lanzillotta, M.; Della-Torre, E.; Milani, R.; Bozzolo, E.; Bozzalla-Cassione, E.; Rovati, L.; Arcidiacono, P.G.; Pattelli, S.; Falconi, M.; Ciceri, F.; et al. Effects of glucocorticoids on B-cell subpopulations in patients with IgG4-related disease. Clin. Exp. Rheumatol. 2019, 37, S159-S166.

106. Fukui, M.; Ogawa, Y.; Shimmura, S.; Hatou, S.; Ichihashi, Y.; Yaguchi, S.; Hirayama, M.; Kawakita, T.; Tsubota, K. Possible involvement of epithelial-mesenchymal transition in fibrosis associated with IgG4-related Mikulicz's disease. Mod. Rheumatol. 2015, 25, 737-743. [CrossRef] [PubMed]

107. Borthwick, L.A. The IL-1 cytokine family and its role in inflammation and fibrosis in the lung. Semin. Immunopathol. 2016, 38, 517-534. [CrossRef]

108. Masunaga, A.; Ishibashi, F.; Koh, E.; Oide, T.; Sekine, Y.; Hiroshima, K. Possible relationship between fibrosis of IgG4-related thymitis and the profibrotic cytokines, transforming growth factor beta 1, interleukin 1 beta and interferon gamma: A case report. Diagn. Pathol. 2018, 13, 6. [CrossRef]

109. Sziksz, E.; Pap, D.; Lippai, R.; Béres, N.J.; Fekete, A.; Szabó, A.; Vannay, A. Fibrosis related inflammatory mediators: Role of the IL-10 cytokine family. Mediat. Inflamm. 2015. [CrossRef]

110. Kotsiou, O.S.; Gourgoulianis, K.I.; Zarogiannis, S.G. IL-33/ST2 axis in organ fibrosis. Front. Immunol. 2018, 9, 2432. [CrossRef]

111. Kawashiri, S.-Y.; Origuchi, T.; Umeda, M.; Nishino, A.; Shimizu, T.; Fukui, S.; Koga, T.; Iwamoto, N.; Ichinose, K.; Tamai, M.; et al. Association of serum levels of fibrosis-related biomarkers with disease activity in patients with IgG4-related disease. Arthritis Res. Ther. 2018, 20, 277. [CrossRef] [PubMed]

112. Francois, A.; Chatelus, E.; Wachsmann, D.; Sibilia, J.; Bahram, S.; Alsaleh, G.; Gottenberg, J.-E. B lymphocytes and B-cell activating factor promote collagen and profibrotic markers expression by dermal fibroblasts in systemic sclerosis. Arthritis Res. Ther. 2013, 15, R168. [CrossRef] [PubMed] 
113. Della-Torre, E.; Feeney, E.; Deshpande, V.; Mattoo, H.; Mahajan, V.; Kulikova, M.; Wallace, Z.S.; Carruthers, M.; Chung, R.T.; Pillai, S.; et al. B-cell depletion attenuates serological biomarkers of fibrosis and myofibroblast activation in IgG4-related disease. Ann. Rheum. Dis. 2015, 74, 2236-2243. [CrossRef] [PubMed]

114. Della-Torre, E.; Rigamonti, E.; Perugino, C.; Baghai-Sain, S.; Sun, N.; Kaneko, N.; Maehara, T.; Rovati, L.; Ponzoni, M.; Milani, R.; et al. B lymphocytes directly contribute to tissue fibrosis in patients with IgG4-related disease. J. Allergy Clin. Immunol. 2020, 145, 968-981. [CrossRef]

115. Puente, A.; Fortea, J.I.; Cabezas, J.; Loste, M.T.A.; Iruzubieta, P.; Llerena, S.; Huelin, P.; Fábrega, E.; Crespo, J. LOXL2-A new target in antifibrogenic therapy? Int. J. Mol. Sci. 2019, 20, 1634. [CrossRef]

116. Perugino, C.A.; Kaneko, N.; Maehara, T.; Mattoo, H.; Kers, J.; Allard-Chamard, H.; Mahajan, V.S.; Liu, H.; Della-Torre, E.; Murphy, S.J.H.; et al. CD4+ and CD*+ cytotoxic T lymphocytes may induce mesenchymal cell apoptosis in IgG4-related disease. J. Allergy Clin. Immunol. 2020, in press. [CrossRef] [PubMed]

117. Yoshikawa, T.; Watamabe, T.; Minaga, K.; Kamata, K.; Kudo, M. Cytokines produced by innate immune cells in IgG4-related disease. Mod. Rheumatol. 2019, 29, 219-225. [CrossRef] [PubMed]

118. Arai, Y.; Yamashita, K.; Kuriyama, K.; Shiokawa, M.; Kodama, Y.; Sakurai, T.; Mizugishi, K.; Uchida, K.; Kadowaki, N.; Takaori-Kondo, A.; et al. Plasmacytoid dendritic cell activation and IFN- $\alpha$ production are prominent production are prominent features of murine autoimmune pancreatitis and human IgG4-related autoimmune pancreatitis. J. Immunol. 2015, 195, 3033-3044. [CrossRef] [PubMed]

119. Watanabe, T.; Yamashita, K.; Arai, Y.; Minaga, K.; Kamata, K.; Nagai, T.; Komeda, Y.; Takenaka, M.; Hagiwara, S.; Ida, H.; et al. Chronic fibro-inflammatory responses in autoimmune pancreatitis depend on IFN- $\alpha$ production are prominent features of murine autoimmune pancreatitis and human IgG4-related autoimmune pancreatitis. J. Immunol. 2017, 198, 3886-3896. [CrossRef]

120. Minaga, K.; Watanabe, T.; Arai, Y.; Shiokawa, M.; Hara, A.; Yoshikawa, T.; Kamata, K.; Yamashita, K.; Kudo, M. Activation of interferon regulatory factor 7 in plasmacytoid dendritic cells promotes experimental autoimmune pancreatitis. J. Gastroenterol. 2020, 55, 565-576. [CrossRef]

121. Furukawa, S.; Moriyama, M.; Miyake, K.; Nakashima, H.; Tanaka, A.; Maehara, T.; Iizuka-Koga, M.; Tsuboi, H.; Hayashida, J.-N.; Ishiguro, N.; et al. Interleukin-33 produced by M2 macrophages and other immune cells contributes to Th2 immune reaction of IgG4-related disease. Sci. Rep. 2017, 7, 42413. [CrossRef] [PubMed]

122. Ishiguro, N.; Moriyama, M.; Furusho, K.; Furukawa, S.; Shibata, T.; Murakami, Y.; Chinju, A.; Rafiul Haque, A.S.M.; Gion, Y.; Ohta, M.; et al. Activated M2 mcrophages contribute to the pathogenesis of IgG4-related disease via Toll-like receptor 7/interleukin-33 signaling. Arthritis Rheumatol. 2020, 72, 166-178. [CrossRef] [PubMed]

123. Tsuboi, H.; Matsuo, N.; Iizuka, M.; Tsuzuki, S.; Kondo, Y.; Tanaka, A.; Moriyama, M.; Matsumoto, I.; Nakamura, S.; Sumida, T. Analysis of IgG4 class switch-related molecules in IgG4-related disease. Arthritis Res. Ther. 2012, 14, R171. [CrossRef] [PubMed]

124. Miyoshi, H.; Uchida, K.; Taniguchi, T.; Yazumi, S.; Matsushita, M.; Takaoka, M.; Okazaki, K. Circulating naïve and $\mathrm{CD} 4{ }^{+} \mathrm{CD} 25^{\text {high }}$ regulatory T cells in patients with autoimmune pancreatitis. Pancreas 2008, 36, 133-140. [CrossRef] [PubMed]

125. Wurster, A.L.; Rodgers, V.L.; Satoskar, A.R.; Whitters, M.J.; Young, D.A.; Collins, M.; Grusby, M.J. Interleukin 21 is a Thelper (Th) cell 2 cytokine that specifically inhibits the differentiation of naïve Th cells into interferon gamma-producing Th1 cells. J. Exp. Med. 2002, 196, 969-977. [CrossRef] [PubMed]

126. Kubo, S.; Nakayamada, S.; Zhao, J.; Yashikawa, M.; Miyazaki, Y.; Nawata, A.; Hirata, S.; Nakano, K.; Saito, K.; Tanaka, Y. Correlation of $\mathrm{T}$ follicular helper cells and plasmablasts with the development of organ involvement in patients with IgG4-related disease. Rheumatology 2018, 57, 514-524. [CrossRef]

127. Cargill, T.; Makuch, M.; Sadler, R.; Lighaam, L.C.; Peters, R.; van Ham, M.; Klenerman, P.; Bateman, A.; Rispens, T.; Barnes, E.; et al. Activated T-follicular helper 2 cells are associated with disease activity in IgG4-related sclerosing cholangitis and pancreatitis. Clin. Transl. Gastroenterol. 2019, 10. [CrossRef]

128. Grados, A.; Ebbo, M.; Piperoglou, C.; Groh, M.; Regent, A.; Samson, M.; Terrier, B.; Loundou, A.; Morel, N.; Audia, $\mathrm{S}$; ; et al. $\mathrm{T}$ cell polarization toward $\mathrm{T}_{\mathrm{H}} 2 / \mathrm{T}_{\mathrm{FH}} 2$ and $\mathrm{T}_{\mathrm{H}} 17 / \mathrm{T}_{\mathrm{FH}} 17$ in patients with IgG4-related disease. Front. Immunol. 2017, 8, 235. [CrossRef]

129. Mattoo, H.; Mahajan, V.S.; Maehara, T.; Deshpande, V.; Della-Torre, E.; Wallace, Z.S.; Kulikova, M.; Drijvers, J.M.; Daccache, J.; Carruthers, M.N.; et al. Clonal expansion of CD4(+) cytotoxic T lymphocytes in patients with IgG4-related disease. J. Allergy Clin. Immunol. 2016, 138, 825-838. [CrossRef] 
130. Maehara, T.; Mattoo, H.; Ohta, M.; Mahajan, V.S.; Moriyama, M.; Yamauchi, M.; Drijvers, J.; Nakamura, S.; Stone, J.H.; Pillai, S.S. Lesional CD4 ${ }^{+}$IFN- $\gamma$ cytotoxic T lymphocytes in IgG4-related dacryoadenitis and sialoadenitis. Ann. Rheum. Dis. 2017, 76, 377-385. [CrossRef]

131. Mattoo, H.; Stone, J.H.; Pillai, S. Clonally expanded cytotoxic CD4 ${ }^{+} \mathrm{T}$ cells and the pathogenesis of IgG4-related disease. Autoimmunity 2017, 50, 19-24. [CrossRef] [PubMed]

132. Wilkinson, T.M.; Li, C.K.F.; Chiu, C.S.C.; Huang, A.K.Y.; Perkins, M.; Liebner, J.C.; Lambkin-Williams, R.; Gilbert, A.; Oxford, J.; Nicholas, B.; et al. Pre-existing influenza-specific CD4 ${ }^{+} \mathrm{T}$ cells correlate with disease protection against influenza challenge in humans. Nat. Med. 2012, 18, 274-280. [CrossRef]

133. Della-Torre, E.; Bozzalla-Cassione, E.; Sciorati, C.; Ruggiero, E.; Lanzillotta, M.; Bonfiglio, S.; Mattoo, H.; Perugino, C.A.; Bozzolo, E.; Rovati, L.; et al. A CD8 $\alpha$ - subset of CD4+SLAMF7+ cytotoxic T cells is expanded in patients with IgG4-related disease and decreases following glucocorticoid treatment. Arthritis Rheumatol. 2018, 70, 1133-1143. [CrossRef] [PubMed]

134. Kessel, A.; Haj, T.; Peri, R.; Snir, A.; Melamed, D.; Sabo, E.; Toubi, E. Human CD19+CD25 ${ }^{\text {high }}$ B regulatory cells suppress proliferation of CD4 ${ }^{+} \mathrm{T}$ cell and enhance Foxp3 and CTLA-4 expression in T-regulatory cells. Autoimmun. Rev. 2012, 11, 670-677. [CrossRef] [PubMed]

(C) 2020 by the authors. Licensee MDPI, Basel, Switzerland. This article is an open access article distributed under the terms and conditions of the Creative Commons Attribution (CC BY) license (http://creativecommons.org/licenses/by/4.0/). 